\title{
Status, Contract, and Promises Unkept
}

\author{
Aviam Soifer†
}

Bob Cover often returned to the moral complexity of rules, his magnificent obsession. In Justice Accused, ${ }^{1}$ for example, Bob brought extraordinary historical knowledge and insight to his study of judges who personally abhorred slavery but who nevertheless upheld the law and returned fugitive slaves to their masters. It is a book that teaches beautifully and rewards each rereading.

In his everyday life, Bob's words and deeds connected almost seamlessly with his published scholarship. He could both provoke and inspire. In numerous ways beyond the classroom, Bob taught about complicity, but never through professorial pomposity. He did not oversimplify the complex, nor did he suggest unquestioning leaps of faith or despair. Instead, Bob wrestled aloud with the profound issues of how law, and narratives about law, may be challenged and changed. He illuminated ways to think, not what to think. Instead of claiming certainty or pretending to a definitive understanding of the boundaries marking the jurisdiction of justice, Bob Cover passionately confronted our deepest moral and legal dilemmas. His struggle was to create more perfect justice instead of a better hierarchy of rules.

I begin this article in memory of my friend with a discussion of the preCivil War slavery decision in Betty's Case. ${ }^{2}$ Exploring the haunting moral complexity of that decision, which allowed a former slave to choose to

\footnotetext{
$\dagger$ Professor of Law, Boston University. I continue to be very lucky in the friends I have and the help they provide. There are many who deserve credit or blame, but I would particularly like to acknowledge Kathryn Abrams, Milner Ball, Dennis Curtis, Haggai Hurvitz, John Leubsdorf, Bruce Mann, Martha Minow, Mark Pettit, Judith Resnik, David Seipp, Carol Weisbrod, Stephen Wizner, and Larry Yackle for aiding and abetting my struggles with this material over the years. I also benefitted from comments made by Kermit Hall, William Wiecek, and those in the audience when I presented a section of this article at the 1981 annual meeting of the Organization of American Historians.

This article is a piece of a larger study of the Thirteenth Amendment, made possible in part by grants from Project '87 and the American Bar Foundation and by summer research opportunities provided by Boston University and the University of Wisconsin Legal History Workshop. A number of research assistants have helped me on this project including, in particular, William Abrams, Lance Cassak, Lisamichelle Davis, Margaret Geary, Jamie Newman, and Edward Reeves; Ken Westhassel has tried valiantly throughout to get things organized and to type my scrawls.

1. R. Cover, Justice Accused (1975) [hereinafter Justice Accused].

2. 20 Monthly L. Rep. 455 (Mass. Nov. 9, 1857). The decision was not officially reported. I have relied on this unofficial report and contemporary newspaper accounts. I first learned of Betty's Case in two footnotes in L. Levy, The Law of THE Commonwealth and Chief Justice Shaw 68 n.19, 69 n.21 (1957) [hereinafter The LAW OF THE CoMmonwealth].
} 
return to slavery, provides a particularly appropriate way to think about Bob Cover and his work.

In other words, Betty's Case is the kind of case within Bob Cover's unique jurisdiction. With his attention to the possibilities of "sacred narratives of jurisdiction" and to the dangers of complicity, ${ }^{3}$ Bob could have done it justice. Bob's published work and the way he lived offered luminous treatment of sobering and often reprehensible aspects of legal history. Yet Bob kept faith and inspired creation of new constitutional worlds through the redemptive power of better narratives. We will be learning from the stories Bob Cover told, and from our stories about Bob, for years to come. Thinking about the bizarre meeting of a young slave known only as Betty and the renowned Chief Justice Lemuel Shaw may help us grieve, celebrate, and remember together.

\section{I. "A Colored Woman, Called Betty"}

\section{A. Prelude: The Legal Setting}

The nation knew Chief Justice Lemuel Shaw of the Supreme Judicial Court of Massachusetts largely for his slavery decisions. ${ }^{4}$ In the 1830's, Commonwealth v. Aves ${ }^{5}$ gave hope to antislavery advocates. In Aves, Shaw adapted Lord Mansfield's famous holding in Somerset's Case ${ }^{8}$ for

3. Bob explored the nexus between narrative and nomos throughout his work. See Jusrice AcCUSED, supra note 1, at 123-30 (discussing complicity and comparing rules and possible changes in rules of games, language, and law); Cover, The Folktales of Justice: Tales of Jurisdiction, 14 CAP. U.L. REv. 179, 183 (1985) [hereinafter Cover, Folktales of Justice] (discussing "sacred narratives of jurisdiction"); Cover, The Supreme Court, 1982 Term-Foreword: Nomos and Narrative, 97 Harv. L. REv. 4 (1983) [hereinafter Cover, Nomos and Narrative] (issue of complicity developed at length).

4. Shaw may well have been the most influential judge in the nation during the thirty years from 1830 through 1860, when he presided over the Supreme Judicial Court of Massachusetts. This was a time when state courts were pre-eminent and Massachusetts law and lawyers enjoyed considerable renown. A well-known witticism about Shaw is attributed to Rufus Choate: "I always approach Judge Shaw as a savage approaches his fetish, knowing that he is ugly, but feeling that he is great." V.W. Brooks, The Flowering of New England, 1815-1865, at 325 (1936). Nevertheless, slavery was an issue that commanded public attention, and Shaw handed down more than his share of famous decisions involving slaves. For a fine discussion of Shaw and many of his decisions, see THE LAW OF THE COMMONWEALTH, supra note 2.

5. 35 Mass. (18 Pick.) 193 (1836); see The LAw of THE Commonwealoth, supra note 2, at 62-71; see also JUSTICE AccUSED, supra note 1, at 250 (Aves and similar decisions ensured that "Shaw's antislavery reputation was as widespread and secure as that of any judicial figure before 1850 ").

6. Somerset v. Stewart, 98 Eng. Rep. 499 (K.B. 1772) (appearing originally in the colonies in 1 Lofft's Rep. 1 (1772)). Scholars have argued at length about what Lord Mansfield actually may have said in Somerset's Case, but they generally agree that the report that reached the American colonies contained Mansfield's label of slavery as so odious as to be permissible only when it was a creature of positive law. The traditional paraphrase of Mansfield's decision was that the air of England was too pure to be breathed by a slave, and that therefore a slave voluntarily brought to England from Virginia by his master immediately became free. See, e.g., D. Davis, The Problem of SLAvery in THE AGE of Revolution, 1770-1823, at 469-522 (1975). See generally W. WiECEk, THE SourCeS of ANTISLAvery ConStitutionalism in AMERICA, 1769-1848, at 20-61 (1977) (describing ambig- 
Massachusetts and for the new federal system. Shaw sought to put his great stature behind a solution to a perplexing conflict of laws problem, an abiding legal complication of divided sovereignty, exacerbated by the complexities of an American nation half-slave and half-free. ${ }^{7}$ Shaw held that, in the absence of positive law commanding slavery, natural law (which embodied a basic legal presumption in favor of liberty) immediately and entirely freed a slave brought into Massachusetts voluntarily by her master. Liberty was general, slavery only a product of local law. ${ }^{8}$ Thus, when Mrs. Slater of New Orleans brought along her six-year-old slavegirl Med on her summer vacation in Massachusetts, Shaw ruled that the girl immediately became free. ${ }^{9}$

The law was entirely different for fugitive slaves. Since federal constitutional and statutory law protected slaveholders' property rights, fugitive slaves did not become free upon entering Massachusetts. Shaw maintained that the highest positive law in the country, the federal Constitution, was premised on assurances to the South that runaway slaves would be returned. ${ }^{10}$ On several occasions, however, crowds of antislavery activists

uous nature of Somerset and its reception in America). For an enthusiastic account of the decision, see A.L. Higginbotham, In the Matter of Color: Race \& the American Legal Process: The Colonial Period 333-55 (1978), and for an intriguing use of the case as part of materials for the study of legal process, see H. Horowitz \& K. KarST, Law, Lawyers and Social Change (1969).

7. See generally P. Finkelman, An Imperfect Urion: Slavery, Federalism, and Comity (1981) (conflict of laws issues involving slaves tested interstate harmony severely); Soifer, Compromise at the Boundaries of Bondage, 10 REv. AM. HisT. 185 (1982) (comity not matter of rights but part of larger constitutional debate). As Don Fehrenbacher demonstrated, the conflict of laws problem readily blended into John $\mathrm{C}$. Calhoun's argument for the exclusivity of federal protection for the rights of property owners, a theme played out tragically first in the Supreme Court and then on the battlefields. D. Fehrenbacher, The Dred ScotT Case: Its Significance in American Law AND Politics 139-41 (1978).

8. In this respect, Levy argues, "Shaw's was a diplomatic performance. He managed to voice northern opinion resolutely, but without rebuke to the South." THE LAW of THE CommONWEALTH, supra note 2, at 64. As Cover emphasized, Americans often looked to natural law to fill gaps in positive law, gaps that appeared throughout the nation's multiform system of laws. JUSTICE ACCuSED, supra note 1, at 17-19. Nonetheless, decisions such as Aves seemed to articulate "a troublesome moral gap" and became important more for emphasizing the distance between morality and law than for what they actually declared local law to be. Id. at 17. Shaw left the actual basis of his decision in Aves somewhat obscure, but in a subsequent decision, the New Jersey Supreme Court took pains to disassociate itself from what the New Jersey judges regarded as the well-known antislavery views of Lemuel Shaw. See id. at 57-58 (citing State v. Post, 20 N.J.L. 368 (1845)).

9. The Aves case took its name from Mrs. Slater's father, Thomas Aves, in whose custody Med was kept. Read narrowly, Shaw's opinion in Aves actually assumed that slavery and even the slave trade did not violate international law, and merely freed Med on a technical application of rarefied doctrines of conflict of laws and comity. Read broadly, Shaw went to considerable lengths to state that slavery is "contrary to natural right" and entirely dependent on local law. Aves, 35 Mass. (18 Pick.) at 217.

10. This view - that an essential constitutional compromise assured northern noninterference with the South's "peculiar institution"-is generally associated with the increased sectional stiffe of the 1830 's, and with decisions such as Aves, which may have heightened southern perceptions of isolation and adverse moral judgments of the southern way of life. Nonetheless, one discovers similar arguments decades earlier, before slavery became a heated political issue. For example, James Madison 
confronted Shaw in his own courtroom and successfully interposed their own, very different ideas about what law or morality might require of Massachusetts citizens faced with the plight of black persons alleged to be fugitive property. For example, a large crowd supported the rescue of a fugitive slave named Shadrach by a number of free blacks of Boston in February, 1851. Although Shaw personally tried to bar the door, the rescuers carried Shadrach from the courthouse and "went off toward Cambridge, like a black squall, the crowd driving along with them and cheering as they went."11

It was a remarkable moment two months later, therefore, when Shaw again defied an antislavery mob and stooped under a chain surrounding his courthouse in order to do what he saw as his constitutional duty: ordering the return of a fugitive slave to the South. ${ }^{12}$ To leading Boston merchants and their political allies, this dramatic scene represented obedience to law. The moment symbolized hope for the survival of the Union. In contrast, leaders of Boston's legal and literary communities unmercifully vilified Shaw, whom they viewed as an accessory to a legal kidnapping. Shaw insisted that his decision was compelled by law; he also regarded it as essential to demonstrate that even Massachusetts would honor the original constitutional compromise that was crucial to survival of the Union, and would keep its part of the bargain that produced the great statutory compromise of $1850 .^{13}$

For many in Boston who vigorously opposed slavery, the spectacle of

argued during the Virginia Ratification debate that slaveholders should adopt the federal Constitution because it would increase their control over runaway slaves. Madison argued that, in contrast, under the Articles of Confederation "the states are uncharitable to one another" when a slave "elopes" from a slave to a free state. Justice ACCUSED, supra note 1, at 88 (quoting 3 J. Elliot, Debates ON the Federal Constitution 453 (2d ed. 1836)); The Federalist No. 54, at 337 (J. Madison) (C. Rossiter ed. 1961) (slaves are "considered by our laws, in some respects as persons, and in other respects as property"). Pennsylvania passed special legislation to assure delegates to the 1787 Convention that they could bring slaves with them without fear of losing them due to their presence in a free state. Cf. Selectmen of Windsor v. Jacob, 2 Tyl. 192, 200 (Vt. 1802) (excluding bill of sale as evidence in suit seeking repayment from slaveowner of funds spent to support former slave, with dictum about Vermont submitting "with cheerfulness to the national constitution" despite contrary views on slavery).

11. S. Campbell, The Slave Gatchers: Enforcement of the Fugitive Slave Law, 1850-1860, at 149 (1968) (quoting C. AdAMs, Richard HenRy DanA, A Biography 182-83 (rev. ed. 1891)).

12. The Law of the Commonwealth, supra note 2, at 72-108.

13. Levy, Sim's Case: The Fugitive Slave Law in Boston in 1851, in L. Levy, JudGmEnts: Essays on AMERICAN Constirutional History 290-92 (1972) (detailing volatile atmosphere in Boston, including mass meetings, rescue plot, and "treasonably violent" address by Wendell Phillips, as well as calls by other members of Boston antislavery leadership to nullify Fugitive Slave Act of 1850). For an excellent, succinct discussion of the Compromise of 1850 and its aftermath, and the rhetoric it helped to generate, see S. GampBell, supra note 11. For a provocative discussion of some of the best-known oratory on that most famous oratorical occasion, see R. FERGUSON, LAW AND LETTERS in AMERICAN CuLture 232-40 (1984) (Daniel Webster "perfected the central image of the law-abiding citizen" and thereby became primary target of younger northern intellectuals for "his devotion to lower law" and his "legal crime"). 
the great Shaw bowing beneath a chain before ascending the bench, there to uphold the "covenant with death,"14 demonstrated that the shame of slavery could never be isolated and that the Slave Power would never be satisfied. The spiralling, passionate clash over basic moral issues grew even more heated several years later when, less than two weeks after President Pierce signed the hated Kansas-Nebraska Act of $1854,{ }^{16}$ an abortive aitempt to rescue a fugitive slave named Arthur Burns left a jail guard dead and Burns in chains. This time, it took a military escort of 2000 men to march the black man through streets of Boston, a city shrouded in mourning with flags flying at half-mast. ${ }^{10}$

It is not difficult, therefore, to imagine the bitterness with which citizens of Boston reacted to news of the decision in the Dred Scott case. ${ }^{17}$ Chief Justice Taney's view of federalism incorporated a belief that it was constitutionally incorrect to treat a black person as a national citizen. Taney thus found it unnecessary for a slave state to accept a free state's classification of a black as free if the black person returned to a slave state. This view particularly galled legal sophisticates among the Boston elite; ${ }^{18}$ and Abraham Lincoln attracted considerable support when he sug-

14. The quote is from William Lloyd Garrison's famous address on July 4, 1854, at Framingham, Massachusetts, accompanying his public burning of the federal Constitution. P. Paludan, a Covenant with Death: The Constitution, Law, and Equality in the Civil WAR ERA 3 (1975). Wendell Phillips apparently began to refer to the Constitution in the words of Isaiah as a "covenant with death and an agreement with hell" a decade before Garrison's dramatic speech. See C. Martyn, Wendell Phillips: The Agitator 166 (1890).

15. Kansas-Nebraska Act, ch. 59, 10 Stat. 277, 277-90 (1854). For a discussion of the Act, see D. FEHRENBACHER, supra note 7, at 181-87.

16. S. Campbell, supta note 11, at 124-32; The Law of the Commonwealth, supra note 2, at 105-06. It proved imposssible to obtain a guilty verdict from a Massachusetts jury in subsequent prosecutions of the would-be rescuers of fugitive slaves. See L. LEVY, supra note 13, at 312 n.48.

17. D. FeHRENBACHER, supra note 7, at 417-48. I have done my own brief survey of some of the press reaction in the months after Dred Scott was handed down in March 1857. To term the response vitriolic and impassioned understates the case. See, e.g., N.Y. Evening Post, reprinted in 27 THE Liberator, Mar. 20, 1857, at 45, col. 4, ("Are we to accept, without question, these new readings of the Constitution-to sit down contentedly under this disgrace . . . to consent that hereafter it shall be the slaveholder's instead of the freeman's Constitution? Never! Never!"'); N.Y. Tribune, reprinted in 27 The Liberator, Mar. 20, 1857, at 45, col. 5 (denouncing Dred Scott as "wicked and false judgment" that makes the Constitution "a bulwark of inhumanity and oppression"); The Commercial Advertiser, reprinted in 27 The LiBerator, Mar. 20, 1857, at 45, col. 6 (Dred Scott is "monstrous usurpation").

18. It is not necessary here to enter the scholarly debate about the relative importance of slavery generally, or the Dred Scott decision specifically, to the coming of the Civil War. It is sufficient to note that even in Massachusetts the status of a slave as a person or as property was contingent, as a matter of law, on the circumstances of the slave's entry into the state. Radically different procedures followed from the initial presumption as to whether a black person was free or a slave. Moreover, Dred Scott seemed to say that Massachusetts courts could no longer decide whether the property rights of slaveholders commanded legal protection. The Dred Seott decision achieved an unusual level of notoriety. In a period before mass print culture and long before modern mass media, courts, lawyers, and legal decisions provided an important form of entertainment. See, e.g., R. ISAAC, ThE TRANSFormation of Virginia, 1740-1790, at 88-94 (1982).

For the general reaction to Dred Scott, see D. FeHRENBACHer, supra note 7, at 417-48; see also V.W. BROOKS, supra note 4 (describing strong antislavery views of Boston literary set). For fine 
gested that the Dred Scott ruling was good for that case and that case only, and that it need not restrict other people in their political views and actions. ${ }^{19}$ But what did Lemuel Shaw think?

\section{B. Betty's Case}

Eight months after Dred Scott, Chief Justice Lemuel Shaw once again faced a legal dispute about the return of a slave to the South.

\section{The Interview}

As was his custom, ${ }^{20}$ Shaw, who was born during the Revolutionary War and was seventy-six years old in 1857, retired into a private room with the party in question. Upon emerging, Shaw "caused the following record to be made." ${ }^{21} \mathrm{He}$ wanted to establish clearly how he proceeded, his findings of the facts, and his legal decision. Shaw elected to write in the first person, rather than in the traditional judicial third-person voice. Shaw thereby appeared more directly responsible than judges usually do

recent treatments of antebellum New England legal culture, see K. Newmyer, Harvard Law School, New England Legal Culture, and the Dialectic of Antebellum Jurisprudence (Apr. 2, 1987) (on file with author); F. Konefsky, Legal Culture in Antebellum Boston (Oct. 1986) (on file with author).

19. See Speech by Abraham Lincoln at Chicago, Illinois (July 10, 1858), reprinted in 2 A. LiNColn, The Collected Works of Abraham Lincoln 385, 396 (R. Basler ed. 1946), and quoted in Cover, Nomos and Narrative, supra note 3, at 53 n.146 (explaining position of "refusing to obey [Dred Scott] as a political rule").

20. Shaw had conducted private interviews of slaves-presumed free because they were voluntarily brought into Massachusetts-beginning in 1832, when he accepted the wish of Francisco, a boy "12 or 14 years of age," to return as a slave to Cuba with his mistress, Mrs. Howard. Commonwealth v. Howard, Daily Atlas, Boston, Dec. 5, 1832, described in The Law of THE Commonwealth, supra note 2, at 61-62. After interviewing an eight-year-old, however, Shaw determined that because "a child of such tender years has no will, no power of judging . . . his will and choice are to be wholly disregarded." Commonwealth v. Taylor, 44 Mass. (3 Met.) 72 (1841), quoted in THE LAw OF THE Commonwealth, supra note 2, at 69 . Levy says of the set of cases from Francisco's return to slavery in 1832 through Shaw's decision to free a slave named Lucas brought into Boston harbor aboard a United States Navy ship in 1844, "In none of these cases was the Chief Justice constrained by statute or precedent to decide as he did: by his own opinions he made and defined the law." Id. at 71.

In continuing to make and define the law to include a private interview with Betty, Shaw may have been inspired by the procedure adopted in other states, though not in Massachusetts, that required a private interview by a judicial officer with a married woman before property she and her husband owned could be conveyed to a buyer. See M. SALMON, Women and THE LAw of Property in EARLY AMERICA 14-40 (1986). Salmon writes that during the period she studied (1750-1830), "Massachusetts lawmakers never gave formal recognition to the principle of coercion. Women did not have private examinations, nor were they required to acknowledge deeds of conveyance in court." Id. at 23 . In this, as well as in a variety of other ways connected to resistance to equity courts, Salmon concludes that the New England states were the least protective of the legal autonomy of women. Id. at $185-93$.

Therefore, while there were models in other jurisdictions for the private interview to protect a married woman from coercion, Shaw was innovating in terms of Massachusetts law when he engaged in such an equitable process in his inquiries into the free choices of slaves. His willingness to continue to improvise in Betty's Case is made more dramatic by Dred Scott.

21. 20 Monthly L. Rep. 455, 456 (1857). 
for whatever pain his judicial power inflicted. ${ }^{22}$ Simultaneously, however, by speaking in the first-person, Shaw shared his dilemma more immediately with the public and yet made his decision seem more compelled and compelling.

Lewis and Laura Sweet came to Boston from Lawrence in response to a habeas corpus petition that female antislavery activists ${ }^{23}$ had filed to challenge the Sweets' detention of "a colored woman, called Betty." $\mathrm{He}$ continued, "I proposed and had an examination of the said Betty apart from the said Sweet and wife, and all other persons." 24 Even to try to imagine this conversation challenges belief in the dialogic communitarian possibilities of legal discourse so fashionable today. ${ }^{25}$ Yet Shaw had conducted such interviews before and, at least on the surface, his opinion betrays no uncertainty about the clarity of the messages exchanged. ${ }^{26}$

22. In a curious way, Shaw was not retreating to formalism here. His opinion in Betty's Case, unlike decisions by him and by the other antislavery judges Bob Cover discussed, did not respond to the gap between personal morality and perceived legal duty by insistently ascribing responsibility elsewhere. Bob Cover called particular attention to judicial rhetoric, and to its cognitive dissonance function, as in the judicial "retreat to formalism," Justice ACCuSED, supra note 1, at 195-267, but Bob also understood that "[t]he judicial conscience is an artful dodger and rightfully so," id. at 201; see also Cover, The Bonds of Constitutional Interpretation: Of the Word, the Deed, and the Role, 20 GA. L. REv. 815 (1986) (discussing pain and death inflicted by judges through actions of others); Cover, Violence and the Word, 95 YALE L.J. 1601 (1986) (describing legal interpretation as "form of practical wisdom"); Cover, Book Review, 68 CoLuM. L. REv. 1003 (1968) (discussing slavery and Vietnam War draft resistance cases as instances of judicial enforcement of immoral laws). By using the first-person in Betty's Case, Shaw departed from the norm. His approach is thus particularly interesting in this case, although one newspaper described it as "a simple, limited case . . . but so far as it went, it reflected the highest credit upon our law, upon its officers, and upon the people." Boston Journal, reprinted in 27 THE LIBERATOR, Nov. 20, 1857, at 186, col. 1.

23. The petition was made by "Lucy Schuyler, a widow, of Lawrence." Boston Herald, reprinted in 27 The Liberator, Nov. 13, 1857, at 183, col. 1. The same report identifies "Mrs. Grover, wife of Simon Grover, of Lawrence" as the party who arranged to bring the habeas petition. At one point, Mrs. Grover "went upon her knees" to implore Betty to "decide to remain free and happy, instead of going back to slavery." Id. Mrs. Grover also had a notably formal exchange with Mr. Lewis Sweet, the slaveowner and the son of the Recorder of Nashville. Mr. Sweet was reported to be "not so imposing, in appearance as his wife," but, after all, Mrs. Sweet was "one of the handsomest ladies that ever honored the Court House with her presence" and "a perfect type of Southern women of good breeding." Id. Mrs. Grover refused Sweet's offer to return a bonnet that Mr. Grover had given to Betty when Mrs. Grover found "the poor thing with nothing but a plantation hat on." Id. According to Mrs. Grover, Betty called upon her and reiterated in front of a dozen ladies that Betty feared that if she were carried back to Tennessee, her owner would die and she would be sold to strangers. Id.

24. 20 Monthly L. Rep. at 456-57.

25. See, e.g., J.B. White, Heracles' Bow: Essays on the Rhetoric and Poetics of the LAw 28-138, 238-40 (1985); J.B. White, When Words Lose Their Meaning: Constrtutions and Reconstitutions of Language, Character, and Community 231-85 (1984); M. Ball, Lying Down Together: LAw, Metaphor, and Theology (1985); Soifer, Reviewing Legal Fictions, 20 GA. L. REv. 871, 893-909 (1986).

26. The interview lasted "about ten minutes." Boston Herald, reprinted in 27 The LibERator, Nov. 13, 1857, at 183, col. 1. The same report describes the presence of "a large crowd of colored and white individuals," id., and "[a] considerable number of colored persons" continued to gather after Shaw's decision. The Traveller, reprinted in 27 THE LIBERATOR, Nov. 13, 1857, at 183, col. 1 (1857). Burrill Smith, who had been a slave himself for 18 years, as well as Peter B. Brigham and an unnamed "colored woman" continued to try to convince Betty to change her mind, though the Sweets 
Shaw explained that he ordered a private examination "that there might be no restraint or intimidation." ${ }^{\prime 27}$ He stressed that the full court previously approved this method. So Shaw and Betty conversed. Betty, as Shaw saw it, was free to speak her mind.

"[I]t appeared to me," Shaw said of Betty, "that she is twenty-five years old, intelligent and capable of judging for herself." ${ }^{28} \mathrm{He}$ also found "that she has a husband in Tennessee and other relatives; that she is much attached to Mr. and Mrs. Sweet; is very well treated by them, and desires to remain and return with them, and this desire she expressed decisively and upon repeated inquiries." ${ }^{29}$ Because the Sweets had voluntarily brought Betty into Massachusetts, Shaw found the law to be clear: Betty now was free. Because Betty was not a fugitive from labor in the sense of the Constitution and the federal statute, the act of voluntarily bringing her into Massachusetts became, according to Shaw, "in effect, an emancipation." 30 Shaw never mentioned that he was defying, or at the very least ignoring, the holding in Dred Scott, though he clearly seemed to do so by considering whether Betty was free, and by asserting the authority of a Massachusetts court to be sufficient to deprive the Sweets of their property. ${ }^{31}$

were always present and the antislavery activists never got the twenty-four hours alone with Betty that they desired. Id. The Traveller described an "absorbing," emotionally charged scene and notes that Betty's master "concluded to remain in the Sheriffs office" until it was time to depart to Lawrence. Id. This report concluded with John A. Andrew, lawyer for the antislavery activists and future Governor of Massachusetts, addressing "the crowd of colored persons upon the outside, urging them to comport themselves in such a manner as to bring credit upon themselves and the cause of freedom which they so dearly loved." Id.

27. 20 Monthly L. Rep. at 455-56.

28. Id. at 457.

29. Id. Newspaper reports make it clear that Betty's "other relatives" included several children. See The Slave Betty, Boston Courier, reprinted in 27 The Liberator, Dec. 11, 1857, at 197, col. 1. Betty's plight touched off a bitter debate in the newspapers. The Boston Courier asked: "[H]ow do these friends of Betty justify themselves for their persistaut [sic] attempts to break the marriage tie, to persuade the wife to abandon her husband, and the mother to desert her children?" Id. This provided a wonderful opening for "C.K.W."-probably Caroline K. Weston, who edited the antislavery Liberty Bell with her sister, Maria Weston Chapman, see 6 THE LETTERs OF William Lloyd GaRRISoN, 1868-1875, at 335 \& n.1 (W. Merrill \& L. Ruckames eds. 1981)-to emphasize that marriage was not actually permitted to slaves and that husband, wife, and children were all entirely subject to "some caprice in the head, or some deficiency in the purse" of their masters. 27 THE LiBERATOR, Dec. 18, 1857, at 202, col. 6. Without directly condemning Betty, C.K.W. argued that if Betty had accepted her freedom, she might have been able to rescue her family. Indeed, wrote C.K.W., "it is even probable that she would have rescued one of these dear ones" and that, in any event, Betty's plight would have awakened sympathy and interest and thereby served the cause of antislavery. Id.

30. 20 Monthly L. Rep. at 456.

31. "The rule was that slavery was local, and liberty general." Id. This portion of the report of the case is written in the third-person. Shaw states "the rule" but then expresses only his "thought" that his formal certification of Betty's freedom would "entitle her to her liberty in Tennessee." Id. This part of the decision may be read as simply recognizing Dred Scott.

Shaw's uncertainty stems not only from Dred Scott, but also from the complicated conflict of laws issue posed by the movement of slaves into freedom and back to slavery. Louisiana continued to honor the older rule-which many Southern jurisdictions had followed before the debate over slavery exploded in the 1850's - that a slave, once freed, could return to a slave state and could later still invoke 


\section{Betty's Free Choice}

For Shaw, the decision in Betty's Case turned on what Betty freely decided. According to Shaw, Betty was free and competent. Moreover, "it was contrary to all the principles of freedom that this or any other person should not exercise a free choice in such a matter."32 Rejecting Betty's decision to remain a slave would have denied her freedom.

To Shaw, the very freedom guaranteed by Massachusetts-" "her right to freedom and protection here"-dictated that Betty was "at free liberty to remain with Mr. and Mrs. Sweet, or go elsewhere, at her free choice."3s Freedom and protection, according to Shaw, were more than merely consistent; the two concepts merged into a right. Massachusetts would grant and protect freedom even for Betty, who was not yet a citizen of Massachusetts and, under Dred Scott, could never be a citizen of the United States. ${ }^{34}$ Indeed, Shaw warned those who might intervene that they were "interdicted and forbidden to interfere with her personal liberty in this respect." 35

The long shadow of Dred Scott, however, reduced even a judge as venerable as Lemuel Shaw to the mere hope that his decision in Betty's Case might someday carry weight toward recognizing Betty's freedom. Shaw insisted that his decision be formally recorded, "so that one, ten, or twenty years hence, the party most interested might have the benefit of the record." " Yet regions of the country, political parties, localities, and even

the freedom established in another jurisdiction. Other Southern states repudiated that rule. See $\mathrm{P}$. Finkelman, supra note 7, at 187-235; Soifer, supra note 7, at 185.

Press commentaries on Betty's Case debated what, if anything, the decision-"coming from a Judge recognized as one of the great luminaries of the bench, than whose name there is none brighter in our judicial history"--said about Dred Scott, and whether there was any law in "Taney's law." Newburyport Herald, reprinted in 27 The LiBERATOR, Nov. 20, 1857, at 186, col. 2.

32. 20 Monthly L. Rep. at 456.

33. Id. at 457-58.

34. Although the meaning of the Dred Scott decision is unclear, Don Fehrenbacher's study clarifies the extent to which Chief Justice Taney's murky opinion represented the opinion of a majority of the Court that federal constitutional protection of property followed the slave-holder. D. FEHRENBaCHer, supra note 7, at 333, 381-84. Taney, Fehrenbacher notes, stressed the issue of domicile. Id. at 385-88, 396-98. A slave passing through Massachusetts, like Betty, could not be considered domiciled in Massachusetts. Therefore, the rest of Taney's constitutional opinion governed and protected the property rights of slaveholders like the Sweets.

35. 20 Monthly L. Rep. at 458.

36. Id. at 456. In certain respects, slaves fared well under Tennessee law as compared with the law of other Southern states. Tennessee courts held that white slaveowners could be indicted and convicted for "murder, mayhem, and manslaughter, committed upon the person of a slave" that they themselves owned. See Worley v. State, 30 Tenn. (11 Hum.) 172, 176 (1850) (upholding conviction for "mayhem" of slaveowner who had castrated an "unruly" slave). Courts also permitted manumission by will, even in cases where the testator had failed to meet statutory requirements. See, e.g., Laura Jane v. Hagen, 29 Tenn. (10 Hum.) 332 (1849) (allowing manumission despite testator's failure to obtain "the assent of the state"); Lewis v. Daniel, 29 Tenn. (10 Hum.) 305 (1849) (allowing manumission despite testator's failure to file petition in presence of requisite number of county judges).

The liberality of Tennessee law had its limits, of course. Slaves continued to be bought and sold like 
families soon bitterly split over which law would bind them. Heated controversy about the extent of legitimate national authority over state, local, and individual freedom hardened into irreconcilable differences, to be settled at Gettysburg and Shiloh and Appomattox. As I will show below, during the Civil War and even more in the years that followed, freedom and protection no longer cohered into the single, unified right Shaw perceived. Indeed, during Reconstruction and its aftermath, a right to freedom often stood in opposition to a right to protection.

In Betty's Case, the tension between individual autonomy and status is clear. I venture to say that no one could easily resolve Betty's terrible dilemma of a choice between family and freedom, the familiar and the unknown. Moreover, a crucial additional factor seriously complicated both the moral-formal dilemma faced by Shaw in his judicial role and the perplexing issues of complicity faced by the antislavery activists. Betty, the would-be beneficiary of their moral judgments, might have been disabled by their very efforts to protect her. ${ }^{37}$ Such additional complexity helps

chattels, see, e.g., Luna v. Edmiston, 37 Tenn. (5 Sneed) 159, 160 (1857) (sale of "mulatto woman ... and her four children"); given as gifts, see, e.g., Hollingsworth v. Miller, 37 Tenn. (5 Sneed) 472 (1858); or distributed by court order to satisfy the demands of creditors, see, e.g., Marley v. Cummings, 37 Tenn. (5 Sneed) 479 (1858). Manumitted slaves could be hired out to cover the cost of shipping them out of the state, see, e.g., Boon v. Lancaster, 33 Tenn. (1 Sneed) 577 (1854). One court refused to permit a manumitted slave to settle in a county where her children-all slaves-resided with their owners. See The Case of F. Gray, 28 Tenn. (9 Hum.) 513 (1848). The unemancipated children of an emancipated slave could not inherit money or property bequeathed them by their father. See Turner v. Fisher, 36 Tenn. (4 Sneed) 209 (1856).

Particularly since Lincoln hoped to keep Tennessee in the Union by not interfering with slave holders and since Tennessee was itself a battleground, see H. Trefousse, The Radical. RepubliCANS: LinCOLN's VANGUARD fOR RACIAL JUSTICE 266-68 (1968), the Civil War years were an especially complex and unsettling time for Tennessee slaves. See J. Cimprich, Slavery's END IN Tennessee 1861-1865, at 19-45 (1985).

I have not yet found out what happened to Betty, but it is possible to imagine that, back in Nashville, she actually watched as Andrew Johnson, the military governor, took command of the city and began to establish his national reputation as a loyal southern unionist. See generally P. MASLowskI, Treason Must Be Made Odious: Military Occupation and Wartime Reconstruction in Nashville, Tennessee, 1862-1865, at 20-32, 121-23 (1978). This led Johnson to the vice presidency and put him on the path to vetoing the Freedmen's Bureau Bill and to clashing with Congress over Reconstruction.

37. A.V. Dicey, the Vinerian Professor at Oxford, asserted that "protection invariably involves disability." A. Dicey, Lectures on the Relation Between Law \& Public Opinion in England DuRing the Nineteenth Century 150 n.1 (1905); see also Soifer, The Paradox of Paternalism and Laissez-Faire Constitutionalism: United States Supreme Court, 1888-1921, 5 LAW \& Hist. Rev. 249 (1987) (discussing Dicey's epigram and antipaternalistic pose of U.S. Supreme Court).

Ironically, some of Shaw's most famous or infamous words concerned paternalism. They appeared in his decision in Roberts v. City of Boston, 59 Mass. (5 Cush.) 198, 210-11 (1849). In the course of rejecting arguments by Charles Sumner and Robert Morris that the concept of equal protection required that the Boston schools be desegregated, Shaw wrote in terms of "paternal consideration" to explain what equal protection entails:

But, when this great principle comes to be applied to the actual and various conditons of persons in society, it will not warrant the assertion, that men and women are legally clothed with the same civil and political powers, and that children and adults are legally to have the same functions and be subject to the same treatment; but only that the rights of all, as they are 
explain why the retreat into formalism beckons so seductively to all of us. $^{38}$

\section{Respecting the Law}

We are left with a large moral question: When is intervention beyond the "measured forms"39 of the law-even when those forms are employed informally as in Betty's Case-warranted or even mandated? In Betty's Case, no one interrupted a string of disquieting acts of collaboration with the Slave Power performed by a young slave woman and a venerable old man. No higher morality led to action by the antislavery mob or to options perceived beyond the slavery-freedom dichotomy.

Shaw transformed his interview with Betty into fact, then law, and then into a fundamental principle of freedom. He declined to defy overtly, or even to criticize, Dred Scott. But neither did Shaw suggest, for example, that since Betty was and had been free for at least the six weeks she had been in Massachusetts, she was owed wages and might continue to have a right to be paid for her labor. ${ }^{40}$ Shaw had once enjoyed a reputation as

settled and regulated by law, are equally entitled to the paternal consideration and protection

of the law for their maintenance and security.

This passage was quoted, probably with some sense of irony, as emanating from a state "where the political rights of the colored race have been longest and most earnestly endorsed," in Plessy v. Ferguson, 163 U.S. 537, 544 (1896).

38. Bob Cover began Justice Accused with a quotation from Shalom Spiegel: "Justice cools the fierce glow of moral passion by making it pass through reflection." JusTICE ACCUSED, supra note 1, at vii. Yet Bob focused throughout his work on the propensity of judges to hide their power behind their rhetoric and to deny that they make moral choices when they do not heed moral claims. I want to broaden Bob's point to suggest that most of us tend not merely to use, but also to seek comfort in the clarity of rules. For, as a rule, "it is only the simple conceptions which take hold of a people's mind," and a "false but clear and precise idea always has more power in the world than one which is true but complex." A. TocQueville, Democracy IN AMERICA 164 (J. Mayer ed. 1969).

39. This is the phrase Melville uses to describe Captain Vere's devotion to law. H. Melville, Billy Budd and OTHer Stories 380 (F. Bush ed. 1986) [hereinafter Billy Budd. Bob Cover introduced Justice Accused with a reflection on Vere's devotion to "forms, measured forms" and the "symmetry of form attainable in pure fiction." Justice AccuSED, supra note 1, at 2-6. Billy Budd can be considered a sustained inquiry about forms of many kinds and their abuses.

40. According to the report of Betty's Case, the Sweets' attorney stated that they "had been travelling with their Servant Betty, in Canada and several of the Northern states, and for the last six weeks had been at Lawrence." 20 Monthly L. Rep. at 455.

There were other realistic options available, however, obscured from view by the tendency of lawyers and activists alike to reduce complex matters to binary choices. For example, accepted distinctions within the law of persons in the 1850's allowed considerable movement away from the freedom/ slavery dichotomy. See, e.g., I. Berlin, Slaves Without Masters: The Free Negro in the ANTEBEllum South (1974); Cottroll, Law, Politics and Race in Urban America: Towards a New Symthesis, 17 Rutgers L. REv. 483 (1986). Justice Joseph Story repeatedly intervened to alter or ignore contracts entered into by seamen because he considered them, as a class, to be vulnerable, "lessthan-equal partners to contracts." K. Newmyer, Supreme CourT Justice Joseph STORY 151 (1985). Similarly, judges frequently sought to protect married women, considered disabled as a matter of common law, who were nonetheless thought to be clearly in need of equitable protection. Norma Basch has demonstrated that Mary Beard overstated this phenomenon in M. BEARD, WoMAN AS A ForCe IN History: A StUdY IN TRAditions and Realiries (1946), but it remains an important aspect of the antebellum legal landscape. N. BASCH, IN THE Eyes OF THE LAW: WOMEN, MARRIAGE 
the nation's leading antislavery judge, but by the 1850's he had become the bane of antislavery radicals-condemned as a Pontius Pilate guilty of "unmanly submission" to immoral federal law."

Yet the antislavery activists who gathered outside Shaw's chambers when Shaw interviewed Betty chose not to intervene. They did nothing to forestall Betty's re-enslavement once they had invoked the court's habeas corpus jurisdiction. Betty was pitied, but to save her from herself would be too paternalistic or too defiant. Though Betty's free will might have been protected, The Liberator later pointed out that Betty's choice would not preclude having her family sold away from her at any moment or finding herself shipped to the auction block without regard to her wishes. ${ }^{42}$ Since the nineteenth century was a time of tremendous personal and economic uncertainty, even well-treated slaves often were sold when

ANd Property in Nineteenth-Century New York 34-35 (1982). Moreover, the complicated patterns in the legal treatment of free blacks, sailors, and women in the antebellum period illustrate that reigning formal and practical legal categories permitted the severing of social, political, and civil rights, as well as further subdivision. See J. KetTner, The Development of AmErican CrrizenSHIP, 1608-1870 (1978); Minow, 'Forming Underneath Everything That Grows': Toward a History of Family Law, 1985 Wis. L. REv. 819, 857-84.

In Betty's Case, either Shaw or the antislavery activists also might have tried to raise the economic stakes for the Sweets in a variety of ways, or to have undertaken efforts to purchase the freedom of Betty's family. In the earlier fugitive slave case of Latimer, for example, the purchase of his freedom resolved the controversy. THE LAW of THE CommonweALTH, supra note 2, at 84 . The subsequent purchase of Frederick Douglass's freedom caused a split in abolitionist ranks. Ironically, William Lloyd Garrison supported that purchase with a practical, ameliorist argument: "To save a fellowbeing, it is no crime sometimes to comply with even unjust demands." A. KRAdrTOR, MEANS AND Ends in american abolitionism: GarRison and His Critics on Strategy and Tactics, 1834-1850, at 222 (1967).

41. JUSTICE ACCUSED, supra note 1, at 212, 250.

42. It is easy to overlook the point, but important not to lose sight of the terrible insecurity directly connected to the fact that slaves were property. In summarizing Thomas B. Chaplin's plantation journal, Theodore Rosengarten puts it this way:

The lesson of Chaplin's journal, illustrated time after time, is that nothing but a white man's conflicting claim could limit a master's property rights in a Negro-not the immunities given to slaves by law, nor the sentiments of kind owners, nor the powers of independent black institutions. Chief of all property rights was the right to transfer ownership-to sell, deed, or bequeathe title in a Negro to another white person. Removal from one's relations and familiar surroundings was a permanent prospect for every slave. A death or marriage in the master's family, a foreclosure or court judgment for debt, an acquisition or disposal of land, was invariably an event in the formation, erosion, or breakup of the black community. Whether the cause brought joy or sorrow to the whites, its frequent consequence was a measure of pain to the blacks. One did not have to be a troublemaker to face removal, which, among punishments meted out to felons and chronic malcontents, was second in severity to death; one only had to be a chattel owned by a mortal master.

T. Rosengarten, Tombee: Portratt of a Cotton Planter 151-52 (1986). This uncertainty led, in turn, to awful scenarios, such as one described by Rosengarten, when a court ordered that a slave named John be sold to pay a debt. John was given "a ticket to go look for a master" and tried desperately, but with little success, to get himself sold to a master who would treat him well. Id. at 195-96. 
their masters died or suffered financial setbacks. ${ }^{43}$ The antislavery activists condescended to Betty, ${ }^{44}$ but left her free to choose.

In essence, the abolitionists' restraint, Shaw's decision, and Betty's choice shared a common feature: They all underscored the power of the individualistic assumptions at the core of nineteenth-century law. The conundrum of autonomy and paternalism confronted in this case raised the issues at the core of Justice Accused. Moreover, this conundrum foreshadowed the dilemma of what to do with, to, or for the freedmen after the Civil War. It is because the "fearful symmetries" 40 lined up so vividly in Betty's Case that decisions to act or not to act in her case still strike us as profoundly discomforting. Betty's Case also brings into focus the tension between status and contract that helps to explain the failure of congressional efforts to protect civil rights in the immediate postbellum period.

Betty's Case illustrates that freedom is a continuum rather than a binary choice. Betty had little room to maneuver along the continuum. Shaw had many more options, ranging from delay, to equitable interventions of various kinds, to public defiance of Dred Scott. The antislavery activists also might have acted to prevent Betty's return to what they considered the lawless state of Tennessee. But Shaw invoked the principle of freedom to exaggerate his constraints, and the complexity of the issue rendered the antislavery mob immobile. They all decided not to intervene. Inaction is also a moral choice. Moderation in confronting evil may be "the invaluable understrapper of the wicked man" because "the moderate man may be used for wrong, but [is] useless for right."16

Everyday intuitive notions of individual freedom inherent in contract law were at once a crucial part of, and a hindrance to, significant congressional efforts to undertake reform. The small Boston circle composed of Shaw, Betty, and the antislavery petitioners before the Civil War, like

43. See L. Friedman, Total Justice 47-50 (1985) (describing life in nineteenth century as "a drama of tremendous uncertainty").

44. When Mrs. Grover's pleas to Betty were unavailing, according to the Herald, Mrs. Grover declared that thereafter she would never interfere with slaves, as they did not possess "backbone enough" to suit her. Boston Herald, reprinted in 27 THE LIBERATOR, Nov. 13, 1857, at 183, col. 1 (1857). The paper mentioned this comment by Mrs. Grover in the same sentence that reported that Mrs. Grover's dress was damaged when the crowd rushed up the courthouse stairs after Betty. The report may have been intended to deprecate the commitment of women to the antislavery cause, though the importance and tenacity of that commitment is amply documented. See, e.g., A. KRADITOR, supra note 40, at 39-77; R. SEWELl, BALlots FOR FREEDOM: ANTISLAVERY PoliticS IN THE UNITED STATES, 1837-1860 (1976).

45. JUSTICE ACCUSED, supra note 1, at 3. This is Bob Cover's term for Captain Vere's decision, after Vere "really squirmed" to do the job of hanging Billy Budd. It may have been borrowed from William Blake's poem, "The Tiger."

46. These are the words of "the Missourian" named Pitch in H. Melville, The ConfidenceMan: His Masquerade 15 (H.B. Franklin ed. 1967). For an argument that Pitch symbolizes "the central position that slavery occupies in Melville's indictment of America, and the pivotal role he ascribes to it in determining the nation's future," see C. KARCHER, SHADOW OVER THE Promised LAND: SLAVERY, RACE, AND VIOLENGE in Melville's AMERICA $237-57$ (1980). 
blacks, Radical Republicans, and most other Americans, believed deeply in the right of individuals to make and enforce whatever contracts they wished. Freedom of contract was a critical element in the prevailing definition of civil rights, yet judicial efforts to enforce the right to contract formed a substantial barrier against protection of freedmen.

\section{A Conundrum of Moral Complexity and Complicity: Status and Contract}

Legal, familial, and communal relationships suffuse decisions to act or not to act. Yet we can see a mirror image of Shaw's decison in favor of autonomy within Betty's own choice (at least if we credit Shaw's report). Their decisions, together with the inaction by the antislavery activists, underscore how manipulation of the concepts of status and contract could entangle former slaves in a web stretching between fears of excessive paternalism and excessive autonomy. Abstract legal principles of contract easily masked racism or indifference; failure to protect freedmen easily could be defended as a decision not to intrude on their freedom.

I want to explore next how Betty's Case and the role of the law during Reconstruction and its aftermath together challenge Sir Henry Maine's claim that "the movement of the progressive societies has hitherto been a movement from status to contract." 47 Most Americans surely did not notice Maine's evolutionary theory when he first published it in 1861, and the Civil War dampened Americans' teleological faith for some time. When the war ended, however, Congress tried to transform slaves and Southern society, and, in effect, to recapitulate Maine's progressive evolution rapidly through constitutional amendments and statutes. The notorious failure of that effort and the rise of the sharecropping system, which sometimes imposed even more virulent forms of servitude on former slaves such as the convict leasing system, demonstrates anew that there is a chasm between the moment of liberation and the attainment of freedom. ${ }^{48}$

I will return in conclusion to Bob Cover's Justice Accused and to an

47. H. Maine, Ancient Law: Its Connection with the Early History of Society and Its RelAtion to MODERN IDEAS 182 (1861). As specific examples, Maine uses the movement from slave status to free contract, and the development from family hierarchy to individual independence. Id. at 136-38. Though nearly everyone learns of Maine's aphorism in law school, this does not mean, of course, that everyone accepts it or learns the extent to which Maine himself qualified his observation. See, e.g., M. Cohen, The Basis of Contract, in LAw ANd THE Social ORder 69 (1982); Jamieson, Status to Contract-Refuted or Refined, 39 CAMBridge L.J. 333 (1980); see also M. Glendon, The New Family and THe New Property (1981) (provocative treatment of somersaulting legal perceptions of family and employment relationships).

48. This distinction is not only common in discussions of revolutionary movements, see, e.g., $\mathrm{H}$. Berman, Law and Revolution: The Formation of the Western Legal Tradition (1983), but is also central in the basic Western text on liberation and redemption, the Exodus story. See generally M. Walzer, Exodus and Revolution (1985) (study of Exodus as political idea about redemption, liberation, and revolution). 
important story within the story of Herman Melville's Billy Budd, Sailor. Bob began his book by developing the connection between Melville and his father-in-law, Lemuel Shaw; then Bob used that connection to explore larger themes about judges, moral complexity, and complicity. Melville also often explored the consequences that follow decisions to remain aloof or uninvolved. One thinks immediately, for example, of Bartleby, the Scrivener and of Bartleby's strong preference not to act. ${ }^{49}$ By focusing on the minor character of the surgeon in Billy Budd, I suggest a powerful connection between repeated decisions against intervention made by influential legal actors and a central, haunting theme in the legal history of race relations in the United States. ${ }^{.0}$ In this concluding section, I address the intersection of legal history and myth, a domain where Bob Cover worked and lived with greatness.

\section{Multiform Law and Simple Assumptions: From Contraband to FreEdom}

The United States already had a particularly mixed and multiform system of law in the antebellum period, but the process of waging the war and securing the peace entailed changes so great as to suggest a new legal order. ${ }^{51}$ Despite the defense of slavery in paternalistic terms (a theme elucidated in much of the best recent work on slavery $)^{\mathbf{6 2}}$ prior to the war, the

49. Bartleby, of course, simply reiterates in a mild, firm voice, "I would prefer not to" and thereby aggravates and activates the equity lawyer who narrates the story, Bartleby, in BilLY BUDD, supra note 39, at 3. Another barbed form of inaction occurs in the course of the deception of Amasa Delano following the slave revolt in Benito Cereno. The colossal, noble slave Atufal play-acts his unwillingness to ask pardon of the Spanish captain, even to have his chains removed, saying only, "No, I am content." Id. at 183.

50. In the late-nineteenth century decisions, as in recent practice, the United States Supreme Court emphasized the need to prove discriminatory motivation. See, e.g., Plessy v. Ferguson, 163 U.S. 537,551 (1896) (argument that enforced separation of two races imposes a badge of inferiority is a fallacy, since "[i]f this be so, it is not by reason of anything found in the act, but solely because the colored race chooses to put that construction on it"); Memphis v. Greene, 451 U.S. 955 (1981) (closing street that passed through white neighborhood, thereby cutting off traffic from black neighborhood to public park, did not violate civil rights statute or Constitution since no proof of discriminatory motive). For a discussion of the search for discriminatory motive both historically and in the context of City of Mobile v. Bolden, 446 U.S. 55 (1980), see Soifer, Complacency and Constitutional Law, 42 Oнго ST. L.J. 383 (1981).

51. See, e.g., E. Ayers, Vengeance \& Justice: Crime and Punishment in the 19th CenTURY AMERICAN SOUTH 141-82 (1984) (describing complicated, violent, paradoxical culture of crime and punishment in antebellum South); H. HyMaN \& W. WIECEK, EQUAL JusTiCE UNDER LAw: Constitutional. Development, 1835-1875, at 386-438 (1982) (discussing broad purposes and departures in federal legislation and constitutional amendments). See generally L. PospisiL, ANTHROpology of LAw: A Comparative Theory 97-126 (1971) (anthropological perspective on mixed aspects of legal systems generally); Soifer, Review Essay, Protecting Civil Rights: $A$ Critique of Raoul Berger's History, 54 N.Y.U. L. REv. 651, 655-70 (1979) (Civil War as watershed).

52. For the controversial introduction to the modern debate, see S. Elkins, SLAvery: A ProbLEM IN AMERICAN INSTITUTIONAI AND INTEL...eCTUAL. LIFE (1959) (comparison of American slaves to concentration camp victims and discussion of identification with oppressors). See generally $\mathrm{M}$. Cunliffe, Chattel Slavery and Wage Slavery: The Anglo-American Context, 
South, like the North, tried to balance reason and sentiment, humanity and interest. As the debate over slavery became increasingly impassioned in the 1850's, some southern states actually enacted statutes that allowed free blacks to escape Northern wage-slavery by entering into bondage under the masters of their choice. ${ }^{53}$ These statutes apparently were purely symbolic. Yet they call to mind a problematic aspect of Lord Northington's recognition that "[n]ecessitous men are not, truly speaking, free men." 14 A problem in any consideration of the morass of contracts and disputes about them, of course, is the determination of how necessitous or unfree someone has to be before relief from an apparent contractual obligation becomes appropriate. Even during the heyday of legal formalism, for example, it appeared obvious to Justice David Brewer and a unanimous Supreme Court that "[i]t is within the undoubted power of government to restrain some individuals from all contracts, as well as all individuals from some contracts." ${ }^{\text {"ss }}$ Nonetheless, it seems clear that contract law

1830-1860 (1979) (paternalism/autonomy debate between North and South); E. Genovese, Roll, Jordan Roll: The World the Slaves Made (1972) (focusing on role of paternalism in defense of slavery, but also as concept mandated by slaves to protect themselves); L. HARTZ, THE LIBERAL Tradition IN AMErica 145-201 (1955) (Whigs failed to unite capitalism and democracy; South increased paternalistic claims in contrast); J. RoARK, MASTERS Wrthout Slaves: SoutherN Planters in the Civil War and Reconstruction 72-74 (1976) (describing southern argument for slavery as in blacks' best interest); D. Roberts, PATERnalism IN EARLy VICTORIAN ENGLAND (1979) (analyzing paternalistic attitudes and beliefs of English elite class of same period); K. STAMPP, The Peculiar InStTtution 322-30 (1956) (noting paternalism of minority of slaveholders toward some slaves); W. Taylor, Cavalier \& Yankee: The Old South and AMerican National Character 145-244, 261-324 (1961) (describing paternalism as core element of southern character); M. Tushnet, The AMERICAN LAw OF Slavery, 1810-1860: Considerations of Humanity and Interest 36 (1981) (southern slaveholders had difficulty explaining paternalism in northerners' language of "individualism"); Donald, The Proslavery Argument Reconsidered, 31 J.S. Hist. 3 (1971); Glickstein, 'Poverty is Not Slavery': American Abolitionists and the Competitive Labor Market, in Antislavery Reconsidered: New Perspectives on the Abolitionists 195, 214-17 (L. Perry \& M. Feldman eds. 1979); Greenberg, Revolutionary Ideology and the Proslavery Argument: The Abolition of Slavery in Antebellum South Carolina, 42 J.S. Hist. 365 (1976).

53. See, e.g., T. Wilson, The Black Codes of THE South 41 \& n.82 (1965) (citing Virginia statute). Massachusetts included a similar provision in its first codification of law, the Body of Liberties, in 1641 and later broadened the opportunity to consent to be a slave. See G. MOORE, Notes ON THE History of Slavery in Massachusetrts 12-15 (1866). Pride of place for the formal abolition of slavery in the United States belongs to Vermont, but even the document that did so, the Vermont Constitution of 1777 , explicitly continued to permit consensual slavery. VT. ConST. art. I, $\$ 1$.

54. Russell v. Southard, 53 U.S. (12 How.) 139, 152 (1851) (quoting Vernon v. Bethell, 2 Eden 113 (1762)); see also L. Friedman, Contract LAw in AMERICA 93-96, 185-86, 194-95 (1965) (discussing use of law as instrument of social policy); M. Horwitz, The Transformation of AMERICAN LAW, 1780-1860, at 160-210 (1977) (19th century rejection of "substantive fairness" justification of contract law). For entertaining and wise descriptions of contract, law, and the history of legal thought, see G. Gilmore, The Ages of American Law (1977); G. GiLmore, The Death of CoNTRACT (1974). For an insightful discussion of the problem of voluntary slavery in the context of nineteenth century American utopian communities, see C. WEISBROD, THE Boundaries of UTOPIA 200-07 (1980).

55. Frisbie v. United States, 157 U.S. 160, 165 (1895) (upholding conviction of lawyer for charging more than $\$ 10$ set by federal law as maximum fee for processing military pension claim). The current version of this restriction on the fee that may be charged for processing federal military pension claims-still set at \$10-was upheld in Walters v. National Ass'n of Radiation Survivors, 105 S. 
became increasingly formalized before the Civil War, and that formal contract doctrine enjoyed its greatest dominance beginning in the decades after the war.

Justice Joseph Story emphasized the formalist, either-or quality of judicial review of contracts when he wrote in 1836 in his Equity Jurisprudence:

For Courts of Equity, as well as Courts of law, act upon the ground, that every person, who is not, from his peculiar condition or circumstances, under disability, is entitled to dispose of his property in such manner and upon such terms, as he chooses; and whether his bargains are wise and discreet, or otherwise, profitable or unprofitable, are considerations, not for Courts of Justice, but for the party himself to deliberate upon. ${ }^{58}$

Contract doctrine dominated American legal culture. As Willard Hurst put it, the first seventy-five years of the nineteenth century were "[a]bove all else, the years of contract in our law." ${ }^{.37}$ By the postbellum years, it had become increasingly unlikely that courts would look beyond the forms law uses to capture a meeting of minds in order to do justice. ${ }^{58}$

There was, and still is, an important tension between the formal assumption of free-will bargaining among individuals in contract law and

Ct. 3180 (1985). Writing for the majority, then-Justice Rehnquist explained that the doctrine of Lochner v. New York, 198 U.S. 45 (1905) "is fortunately long gone, and with it the condemnation of rational paternalism as a legitimate legislative goal." Id. at 3190 . Trends in actual judicial applications of Justice Brewer's point are difficult to spot. When are certain categories of disability likely to lead to judicial intervention? What "operative facts" will be deemed sufficiently unfair to produce judicial invalidation or reworking of contractual obligations? As Grant Gilmore put it, "Corbin counseled not only that we should study all the cases but that we should study them not so much for their doctrinal statements as for what he liked to call their 'operative facts.'" G. GiLMORE, THE Ages of AMERICAN LAW, supra note 54, at 79. For an indication that Corbin and Williston were not as far apart as our use of them as symbols in intellectual legal history tends to suggest, see Williston, Freedom of Contract, 6 CoRnell L.Q. 365, 379 (1921) ("The extent to which freedom of contract should be limited inevitably becomes a question of degree to which not even an attempt at an answer can be made without reference to time, place, and circumstance . . ..").

56. J. STORY, CoMmentaries ON EQUiTY JURISPRUdence $\S \S 245-247$, at 249-51 (1836), quoted in K. NEWMYER, supra note 40, at 294-95.

57. J.W. HuRst, LAW and the Conditions of FREedom in the NineteEnth Century UNITED STATES 18 (1956) (belief in and manipulation of contract law central to "release of energy"); see also E. Foner, Free Soil, Free Labor, Free Men: The Ideology of the Republican PARTY BEFORE THE Civil WAR 11-39 (1970) (ideology of freedom of contract basic to growth of Republican party); Dyson, Contract Stability in Wartime: The Example of the Confederacy, 19 AM. J.L. HisT. 216 (1975) (Confederate attorneys general adhered strictly to contract precedent). For a magisterial discussion of contemporaneous developments in English law, see P. ATIyAh, ThE Rise and Fall of Freedom of Contract (1979).

58. Though theories of the phenomenon vary, legal formalism undeniably had set in with a vengeance by the 1860's. See, e.g., Justice ACCUSED, supra note 1, at 200; G. GiLMORE, supra note 54, at 41-67; M. HoRwitz, supra note 54, at 253-66. See generally M. White, Social Thought IN America: The Revolt Against Formalism (1957) (cross-disciplinary intellectual history of assault on formalism in Progressive era). 
the categorization rules employed in other legal realms. ${ }^{59}$ The process of stripping away entire groups from the sui juris paradigm in contract law was already well underway by the beginning of the Civil War. Even as committed a votary of legal science as Joseph Story, for example, had attached exceptions and caveats to his "forceful endorsement of the will theory of contract." ${ }^{00}$ Most important, the Civil War itself shook and recast the entire legal mix.

I turn first to the remarkably rapid transformation of the legal status of blacks during the Civil War. Then, I consider briefly the effect of the commitment to freedom in the Thirteenth Amendment and the statutes premised on its authority. In conclusion, I discuss why the legacy of forty years of wandering following slavery was not even an approach to the promised land, but instead an almost complete evisceration of statutory and constitutional promises made to the freedmen.

\section{A. The Status of Former Slaves}

During the Civil War, the legal status of slaves in both North and South changed dramatically. North and South placed slaves in shifting categories both through law and out of military necessity. By the end of the war, the Confederacy was offering freedom to slaves who would fight for the Lost Cause. ${ }^{61}$ Though restricted in scope and questionable in constitutionality, Lincoln's Emancipation Proclamation was only the most famous step in the rapid legal transformation of the "dark human cloud that clung like remorse" $e^{\prime 2}$ to Union troops for protection.

59. For deservedly famous analyses of the idea that ethical issues lurk in contract cases, see, for example, Dawson, Economic Duress-An Essay in Perspective, 45 Mrch. L. REv. 253, 281-90 (1947); Kessler, Contracts of Adhesion-Some Thoughts About Freedom of Contract, 43 CoLUM. L. Rev. 629 (1943); Llewellyn, What Price Contract?-An Essay in Perspective, 40 Yale L.J. 704, 731-37 (1931); see also W. FaulKner, The HamLet 317 (1940) ("If a man aint got gumption enough to protect himself, it's his own look-out . . . ."). See generally Gordon, Macaulay, Macneil, and the Discovery of Solidarity and Power in Contract Law, 1985 WIS. L. REv. 565; Kronman, Paternalism and Contract Law, 92 YALE L.J. 783 (1983); Kennedy, Distributive and Paternalist Motives in Contract and Tort Law, with Special Reference to Compulsory Terms and Unequal Bargaining Power, 41 MD. L. REv. 563 (1982); Macneil, Relational Contract: What We Do and Do Not Know, 1985 WIs. L. Rev. 483; Klare, Book Review, 54 N.Y.U. L. REv. 876 (1979).

60. K. NEwMYER, supra note 40 , at 294 . Story was famous, for example, for a series of decisions in which he intervened to protect sailors from themselves and the contracts they had made. He defined seamen as "special wards" because of their "rashness, thoughtlessness and improvidence." Id. at 151 (quoting Brown v. Lull, 4 F. Cas. 407 (C.C.D. Mass. 1836) (No. 2,018)). For a discussion of similar paternalism toward sailors against a backdrop of federal statutory changes and the Thirteenth Amendment, and a description of enthusiastic judicial intervention purportedly on behalf of sui juris individuals freely bargaining together, see Soifer, supra note 37, at 251-52, 262-63.

61. See E. Thomas, The Confederate Nation 1861-1865, at 290-92 (1979). The Confederate approach followed a 1735 Georgia statute on the same subject. See A.L. HigGinBotham, IN THE MATTER OF Color 216-27 (1978); Soifer, Slavery and the Law: A Study in Contradiction (Book Review), 56 TEX. L. Rev. 1319, 1322-26 (1978).

62. See W.E.B. DuBois, The Souls of Brack Folk 18 (1903). The best work specifically on the Emancipation Proclamation remains J.H. Franklin, The Emancipation Proclamation 
In the early stages of the war, slaves who came behind Union lines were defined as "contraband," in keeping with the analysis of Edward Pierce, a Boston lawyer who tried to sort out the confused legal status and impact of the war in an Atlantic Monthly article in November, $1861 .^{.33}$ Pierce claimed that, at a minimum, slaves who escaped or were captured by Union troops enjoyed the protections of Magna Charta and the Declaration of Independence, though their constitutional status remained obscure. This appeal to fundamental law soon became popular among Republican Congressmen.

The history of Major General David Hunter's regional emancipation order in May 1862 underscores how the presence of former slaves among Union troops skewered the old paternalistic ideology of slavery. Hunter, who had once commanded Jefferson Davis and who had risen rapidly in rank after serving Lincoln as a self-appointed body guard in the early days of Lincoln's presidency, decided the time had come to recruit a troop composed entirely of black soldiers. This addition to his general emancipation order was necessary, Hunter explained to headquarters in Washington, so that black troops, without benefit of a "fugitive master law," could "pursue, capture, and bring back those persons of whose protection they have been suddenly bereft." ${ }^{\text {"64 }}$ Hunter's sardonic reversal of the paternalistic justification of slavery, as well as his recognition that black troops could fight for their freedom, did not immediately carry the day; Hunter was transferred in part, it appears, because of his exuberance. ${ }^{65}$ But within two months, Congress decided to seize certain southern land and to free some contraband slaves. Lincoln reluctantly signed the Second Confiscation Act in July, 1862, ${ }^{\text {B8 }}$ the same week that his cabinet received word of Lincoln's proposed emancipation proclamation. Members of executive branch now awaited the good news from the front they thought necessary to support the proclamation. ${ }^{67}$

They had a long wait. In the meantime the public, hungry for war

(1963).

63. Pierce, The Contrabands at Fortress Montoe, AtLantic Monthly, Nov. 1861, at 626, reprinted in E. PIerce, Enfranchisement and Citrzenship: Addresses and Papers 20-52 (1896). For discussions of political and legal changes concerning war aims, and rapidly altered perceptions of blacks during the course of the Givil War, see H. BELZ, A NEW BIRTH OF FreEDOM: The Republican Party and Freedmen's Rights, 1361-1866 (1976); D.T. Cornish, The SabLE ARM: NEGRO TROOPS IN THE UNION ARMY, 1861-1865 (1956); H. TREFOUSSE, supra note 36, at $280-86,344-45$.

64. Quoted in Sproat, Blueprint for Radical Reconstruction, 23 J.S. HIST. 25, 30-31 (1957).

65. Id. This incident also provided early evidence of Secretary of War Edwin Stanton's duplicity. His inconsistency and lack of candor later figured prominently in the struggle surrounding the impeachment of President Andrew Johnson. According to Pierce, blacks in fact had participated militarily as early as August 28, 1861, working a gun aboard the Minnesota during the successful bombardment of South Carolina's Sea Islands. See E. PierCE, supra note 63, at 640.

66. Second Confiscation Act, 12 Stat. 589-92 (July 17, 1862).

67. See J.H. FrankLIN, supra note 62, at 40-43. 
news, learned that "contraband" slaves could farm with impressive success on land from which their owners fled in front of the advancing Union armies. A new federal policy toward slaves, however, curtailed this early "rehearsal for reconstruction." " Lincoln now endorsed General Hunter's renewed demand for black troops and military necessity began to siphon away black farm workers.

Tales about the courage of former slaves fighting in the Union Army transformed their popular image as well as their legal status. The bravery of the black soldiers of the 54th Massachusetts regiment commanded by Robert Gould Shaw probably provided the best-publicized example, but the long years of war supplied countless others. ${ }^{69}$ Increasingly, northern leaders spoke of the former slaves' proven allegiance to the federal government and the government's corresponding obligation to protect those who fought so courageously. ${ }^{70}$

\section{B. Lincoln's Views Transformed and the Thirteenth Amendment Adopted}

The metamorphosis of Lincoln's own distinctly moderate views on the status of blacks is revealing. In his First Inaugural Address, Lincoln en-

68. W.L. Rose, Rehearsal for Reconstruction: The Port Royal Experiment (1964) (story of Sea Islands told largely from perspectives of former slaves); T. ROSENGARTEN, supra note 42 (account of same locale based upon, and reproducing much of, diary of plantation slave owner).

69. There were numerous accounts of the remarkable courage of black soldiers in the assault on Fort Wagner. See, e.g., Pierce, supra note 63, at 640; Cong. Globe, 39th Cong., 1st Sess. 173, 1294 (1866) (speeches by Rep. James Wilson).

Black soldiers were by no means treated equally. Thus, for example, Frederick Douglass was at first unsure about whether to support enlistment of blacks under conditions of formal discrimination in pay and job assignments, and informal discrimination in numerous other ways. See generally J.H. Franklin, From Slavery to Freedom: A History of American Negroes 221-24 (5th ed. 1980); J. McPherson, The Negro's Civil. War: How American Negroes Felt and Acted DURING THE WAR FOR THE UNION (1965).

70. The reciprocal relationship between allegiance and the government's duty to protect formed a central tenet of mid-nineteenth century political theory. For example, Lincoln's quite conservative Attorney General, Edward Bates, issued an opinion distinguishing between civil and political rights and arguing that "the duty of allegiance and the right of protection . . . are correlative obligations, the one the price of the other." $10 \mathrm{Op}$. Att'y Gen. 382, 395 (1862). This theme runs throughout the debates in the 39th Congress. See, e.g., Cong. Globe, 39th Cong., 1st Sess. 605 (1866) (Sen. Trumbull: "[A] positive duty upon us to pass such laws if we find discriminations still adhered to in the States where slavery has recently existed."); id. at 1118 (Rep. Wilson: "I cannot yield up the weapons which slavery placed in our hands now that they may be wielded in the holy cause of liberty and just government."). The obligation of government actively to protect labor in particular was basic to Republican ideology of the period. See E. FoNER, supra note 57, at 11-39, 308-17.

The notion that allegiance and protection are reciprocally related has deep roots in Anglo-American social and legal theory. See, e.g., 1 W. Blackstone, Commentaries * 47-48 ("[T]he original contract of society [is] . . . that the community should guard the rights of each individual member, and that (in return for this protection) each individual should submit to the laws of the community."); J. Calhoun, A Disquisition on Government 55 (R. Cralle ed. 1943) (1853) ("Liberty, indeed, though among the greatest of blessings, is not so great as that of protection . . . ."). See generally Maltz, The Concept of Equal Protection of the Laws-A Historical Inquiry, 22 SAN Diego L. REv. 499, 507-10 (1985). 
dorsed a Thirteenth Amendment that would have guaranteed federal noninterference with property rights in slaves. ${ }^{71}$ Though he eventually would shift to a still different position, by 1863 Lincoln had already moved well beyond his early flirtation with colonization schemes and reversals of emancipation orders issued by his generals. By the time of the Republican convention in June 1864, Lincoln and his party stood firmly for a Thirteenth Amendment that constitutionalized freedom for former slaves. Lincoln now declared that "[i]f the people should, by whatever mode or means, make it an executive duty to re-enslave such persons, another, and

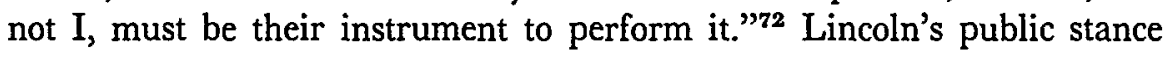
and intensive lobbying efforts were instrumental in securing passage of the Thirteenth Amendment. Widely recognized at the time as a fundamental shift in the constitutional order, the new amendment called forth unprecedented use of national power to protect national rights. ${ }^{73}$ It remains the only constitutional provision held clearly to reach private conduct. From the southern perspective, the Thirteenth Amendment expropriated property worth billions of dollars, without compensation. But the remarks of Senator Lyman Trumbull, a moderate Illinois Republican and chairman of the Senate Judiciary Committee, typified the majority view in Congress. Trumbull argued that the amendment did more than permit Congress to protect the former slaves. He stated:

Congress is bound to see that freedom is in fact secured to every person throughout the land; he must be fully protected in all his rights of person and property; and any legislation or any public sentiment which deprives any human being in the land of those great rights of liberty will be in defiance of the Constitution. ${ }^{74}$

71. A. Lincoln, First Inaugural Address (Mar. 4, 1861), in AbRAham LincolN: His SPEEches AND Writings 579-80 (R. Basler ed. 1946) [hereinafter Lincoln Speeches and Writings].

72. A. Lincoln, Annual Message to Congress (Dec. 6, 1864), in Lincoln SPEECHES AND WRITINGS, supra note 71, at 773, 789. As Richard Sewell summarizes: "What is surprising, perhaps, given the bigotry of the age is that nearly all Republicans defended the Negro's manhood and insisted that he be accorded those inalienable rights set forth in the Declaration of Independence." $R$. SEwELL, supra note 44 , at 327 .

73. The Thirteenth Amendment states: "Neither slavery nor involuntary servitude, except as a punishment for crime whereof the party shall have been duly convicted, shall exist within the United States, or any place subject to their jurisdiction.' U.S. ConsT. amend. XIII, \& 1. Though the process of passage and ratification was controversial, which is hardly surprising in the context of the war still raging, Lincoln supported the amendment with uncharacteristic enthusiasm. Lincoln, whose "educability was outstanding," H. HyMAN \& W. WIECEK, supra note 51 , at 275 , now eagerly sought the Thirteenth Amendment, which he considered the "King's cure for all . . . evils." $8 \mathrm{~A}$. LINCOLN, supra note 19, at 254-55; see H. TREFousse, supra note 36, at 299-304; The Fourteenth Amendment in Light of the Thirteenth: Not Cramped by the Old Technicalities, in H. HYMaN \& W. WIECEK, supra note 51 , at $386-438$.

74. Cong. Globe, 39th Cong., 1st Sess. 77 (1865).

I do not claim that the Congressmen who dominated the 38th and 39th Congresses acted exclusively or even predominantly out of pure benevolence or that they were free of racism. See, e.g., G. FreDrickson, The Black Image in the White Mind: The Debate on afro-American Charac- 
Some Congressmen gave examples of the personal and property rights that were to be protected, ${ }^{75}$ others simply invoked natural law and the Declaration of Independence as the source for the basic civil rights that they insisted the amendment now guaranteed; ${ }^{76}$ many relied on the catchphrases of free labor and Republican ideology. ${ }^{77}$

To ensure that these basic rights would be protected, Congress for the first time included an enforcement clause in the second section of the amendment explicitly authorizing Congress to guarantee the rights in the first section. Congress quickly used this new power to secure a wide range

TER AND DestinY, 1817-1914, at 125-27 (1971); G. Fredrickson, The INNER Givil War: NoRthern INTEllectuals aND THe CRISIS OF THE UNION 183-98 (1965); L. LitwaCK, NoRTH OF Slavery: The Negro in the Free States 1790-1860 (1960); R. Sewell, supta note 44; V.J. Voegeli, Free But Not Equal: The Midwest and the Negro during the Civil War (1967). Struggles with Lincoln and, more significantly and much more bitterly, the congressional battles with Andrew Johnson, were essential factors. See, e.g., W. BROCK, AN AMERICAN CRISIS: Congress and Reconstruction, $1865-1867$ (1963). Compare L. Cox \& J. Cox, Politics, Principle, Prejudice, 1865-1866: Dilemma of Reconstruction America (1963) (arguing dominance by Radical Republicans, ultimately undercut by President Johnson) and H. Trefousse, supra note 36 (arguing that Lincoln and Radicals shared basic desire for national protection of blacks) with M. Benedict, A CoMpromise of Principle: Congressional Republicans and ReCONSTRUCTION 1863-1869 (1974) (arguing a fundamental conservative strain among Republicans). In addition, the desire to keep blacks confined geographically to the South posed a serious problem to Northern Republicans. Southern representation, which would now be based on the entire black population rather than the constitutional compromise of three-fifths, threatened to mean the victory for the Lost Cause at the ballot boxes that it had been denied on the battlefields. Northerners viewed the increase in representation as an immediate political problem of great importance. Consideration of these practical political issues helps explain such phenomena as Thaddeus Stevens's famous speeches concerning Republican ascendancy. See E. Foner, Thaddeus Stevens, Confiscation, and Reconstruction, in Politics and Ideology in the Age of the Givil War 128-49 (1980).

75. See, e.g., Cong. Globe, 38th Cong., 1st Sess. 1319 (1864) (remarks of Sen. Harlan) (Thirteenth Amendment protects every man's "property," "the rewards of his own labor," and "hallowed family relations"); id. at 1199, 1202-03 (remarks of Rep. Wilson, chairman of the House Judiciary Committee) (Thirteenth Amendment guarantees to blacks all basic rights such as freedom of speech and freedom of religion, and establishes "a nation of equals").

76. See, e.g., id. at 1319 (remarks of Sen. Wilson) (Thirteenth Amendment is an affirmative guarantee of "the sacred rights of human nature" enunciated in the Declaration of Independence); CoNG. Globe, 39th Cong. 1st Sess. 1118 (1866) (remarks of Rep. Wilson) (proclaiming Thirteenth Amendment to be a guarantee of "the greater fundamental rights which it is the true office of Government to protect").

77. See, e.g., Cong. Grobe, 39th Cong., 1st Sess. 1295 (1866) (remarks of Rep. Shellabarger) (Thirteenth Amendment fulfills government's obligation to afford the "humblest" citizen "full and ample protection at the cost of the Government" because "the highest obligation which the Government owes to the citizen in return for the allegiance exacted of him is to secure him in the protection of his rights"); J. TENBROEK, EQUAL UNDER LAW 157-97 (1965).

As Senator Henry Wilson of Massachusetts pointed out, passage of the Thirteenth Amendment signified the replacement of a moral rule against slavery with a coercive, positive law prohibition:

The organic law is now right, and instead of dragging or keeping the popular sentiment down,

it is lifting it up to the plane of its own high ideal. He that treats the negro unjustly cannot now, as before, plead the sanction of the Constitution; but he violates human as well as divine law. The gain is, therefore, immense; and it gives the negro and his friends high vantageground in the conflict still in process. Public sentiment may not yet be fully up to its proper enforcement; but the tendency-it is a source of comfort and courage-is toward it.

3 H. Wilson, Rise and Fall of the Slave Power in America 454 (1877); see H. Hyman \& W. WIECEK, supra note 51, at 302-03. 
of civil rights, further demonstrating that it viewed the Thirteenth Amendment as a broad guarantee from the outset.

The Thirteenth Amendment altered federalism. It established an affirmative role for Congress to protect fundamental rights throughout the nation. The constitutional guarantee of universal civil freedom entailed federal protection of individual rights. Yet this protective re-ordering might imply an inequality between freedmen and other citizens. ${ }^{78}$ What did protection of basic civil rights mean in practical terms? The Civil Rights Act of 1866 reaffirmed that the framers and ratifiers of the new constitutional guarantee intended to alter the relationship of former slaves to their former masters as well as the relationship of the states to the federal government. But these law-makers, committed as many of them were to securing the peace that had cost so much blood, could not resolve the pervasive conflict in their legislative scheme between paternalism and individualism. Thus the first right listed within the enumeration of equal rights guaranteed by section one of the Civil Rights Act of 1866 was "the right to make and enforce contracts." 78

That there was a deep ambivalence about how to protect the new freedmen after the Civil War is not surprising; indeed, it haunts us still. ${ }^{80}$ The rub, of course, is in determining who needs protection and in providing it without stigmatizing or disabling alleged beneficiaries. Lincoln's definition of the object of government dramatically reveals this conflict: "[T]o elevate the condition of men, to lift artificial weights from all shoulders; to clear

78. See supra note 37. The best of the excellent work on Republican ideology is still to be found, in my opinion, in E. Foner, supra note 57; D. MONTGOMERy, Beyond EQuality: Labor aND THE Radical Republ.icans, 1862-1872 (1967).

79. Civil Rights Act of 1866 , ch. $31, \S 1,14$ Stat. 27 (current version at 42 U.S.C. $\$ \$ 1981-1982$ (1982)). For an extensive discussion of the context and probable meaning of the passage of this act over President Andrew Johnson's veto, see Soifer, supra note 51, at 690-96. See generally H. BeLz, Emancipation and EQual Rights: Politics and Constitutionalism in the Givil War ERa (1978); M. Benedict, supra note 74; D. Donald, Liberty and Union (1978); H. Hyman, A More Perfect Union: The Impact of the Civil WaR and Reconstruction on the ConstiTUTION (1973)).

80. We still, perhaps increasingly, tend to forget that even John Stuart Mill limited his liberty principle to "human beings in the maturity of their faculties" and further limited the principle to those "capable of being improved by free and equal discussion." J.S. MiLl, ON LIBERTY 9 (R. McCallum ed. 1947). Mill in fact emphasized that "[t]hose who are still in a state to require being taken care of by others, must be protected against their own actions as well as against external injury." Id. He found that category quite extensive when he actually got involved in law-making for India. J.S. MiL, Considerations of Representative Government, in 19 ColleCTED WORKS OF J.S. Mul.: Essays on Politics AND Sociery 562, 567-68 (J.M. Robson ed. 1977) (identifying India as one of the British "dependencies" not "fitted for representative government" and arguing that British domination of such dependencies is a legitimate mode of government only if "it is the one which in the existing state of civilization of the subject people, most facilitates their transition to a higher stage of improvement"). Mill's views on paternalism are discussed in F. BERGER, HAPrinEss, JusTICE, \& Freedom: The Moral \& Political Philosophy of J.S. Mill 265-71 (1984). For a fine recent discussion of similar issues, see Minow, When Difference Has Its Home: Group Homes for the Mentally Retarded, Equal Protection and Legal Treatment of Difference, 22 HARV. C.R.-C.L. L. REv. 111 (1987). 
the paths of laudable pursuit for all; to afford all an unfettered start and a fair chance in the race of life." ${ }^{31}$ Addressing the Georgia legislature in February, 1866, former Confederate Vice President Alexander Stephens provided an ironic echo of Lincoln's words: "Ample and full protection should be secured to the negroes so that they may stand equal before the law in the possession and enjoyment of all rights of person, liberty and property." 82 Paradoxically, however, while the Givil War still raged, Frederick Douglass entered the debate about what to do with the former slaves and insisted: "Do nothing with them. Your doing with them is the great misfortune."83 The American Freedmen's Inquiry Commission added its prestige to Douglass' argument. Although in their preliminary report Commissioners Samuel Gridley Howe, Robert Dale Owen, and James McKaye suggested federal guardianship of former slaves, in their final "blueprint for reconstruction" these prominent do-gooders endorsed a "let alone system." No government aid should be offered, Howe believed, "unless our protection is demanded by the sufferers themselves."

We cannot know how Lincoln would have directed the federal government to protect former slaves. He may have intended to provide forty-acre plots, to be purchased by freedmen with profits they made by farming confiscated southern land. We do know that the promise of forty acres (with or without the mule) was more than a mere pipe dream. ${ }^{86}$ General

81. A. Lincoln, Message to Congress in Special Session (July 4, 1861), in Lincoln SpeEches AND WRITINGs, supra note 71 , at 594, 607.

82. Stephens is quoted at $5 \mathrm{~J}$. Rhodes, History of THE United States 560 (1904). It is difficult to determine fully what Lincoln or Stephens intended. Scholars have examined carefully Lincoln's views on race and free labor. See, e.g., L. CoX, Lincoln and BlaCk FREedom: A STUdY in Presidential. Leadership (1981); E. Foner, supra note 57, at 260-300; B. QUarles, LinCOLN AND THE NEGRO (1962); see also Boritt, Looking for Lincoln in the 1980's, N.Y. Times, Feb. 8, 1987, Book Review, at 1, col. 1 .

Stephens is perhaps more of a puzzle. In his 1866 speech, he may have been playing to a northern or congressional audience, which was carefully watching events in the newly constituted southern legislatures, or he may have been echoing the paternalism of the old order. In any case, Stephens did go on to remind his fellow Georgians of the loyalty of many blacks to their masters even during the Civil War and to assert that "[l]egislation should ever look to the protection of the weak against the strong." 5 J. RHODES, supra, at 561.

More important than Stephens's motivation is his nominal dedication to the vague notion that legislatures should intervene to assure a fair and equal start in the race of life-a notion also voiced by many congressional leaders. E.g., CoNG. Globe, 39th Cong., 1st Sess. 1118, 1294 (1866) (remarks of Rep. Wilson); id. at 605 (remarks of Sen. Trumbull).

83. 3 The Life and Writings of Frederick Douglass 188-89 (P. Foner ed. 1955).

84. H. BeLZ, supra note 63, at 69-74 (quoting letter from Samuel Gridley Howe to Sen. Charles Sumner (Dec. 19, 1863)); Sproat, supra note 64, at 34-44 (describing Commission's formula as "give them the means, give them a chance, and then let them alone"). The Commission's notion of giving blacks a chance included confiscations of Southern land and constitutional amendments to protect the civil and political rights of blacks.

85. H. BELZ, supra note 63 , at 74 .

86. See, e.g., Cox, The Promise of Land for the Freedmen, 45 Miss. Valley Hist. Rev. 413, 440 (1958); see C. Oubre, Forty Acres and a Mule: The Freedmen's Bureau and Black LAND OWNERSHIP (1978); Abbott, Free Land, Free Labor, and the Freedmen's Bureau, 30 AGRIC. Hist. 150 (1956); see also E. Foner, supra note 74, at 128-49 (discussing Thaddeus Stevens' role in 
Banks took some preliminary steps towards land redistribution in Louisiana during the war. ${ }^{87}$ General William T. Sherman's famous Field Order No. 15 specifically allocated forty-acre plots to freed slaves. ${ }^{88} \mathrm{We}$ also know something of Lincoln's hopes, suggested, for example, in his instruction to General Banks, to create "some practical system by which the two races could gradually live themselves out of their old relation to each other, and both come out better prepared for the new." 89

\section{Settled Expectations}

Even more than nineteenth century Americans' aversion to redistribution of property by government-at least when the redistribution was visi$\mathrm{ble}^{80}$ - the ideology of formalistic contract law was, I believe, directly implicated in the emergence of a practical peonage system after the war. Recently, scholars have debated the relative efficiency of slavery and of the sharecropping system with considerable intensity. ${ }^{91}$ Moreover, through Leon Litwack's marvelous kaleidoscopic portrait of complex human relationships ${ }^{82}$ - complementing a host of other fine studies of the chaotic so-

debate over confiscation of rebel property). The best-told story of the bureaucratic wrangling within the Freedmen's Bureau over what the freedmen should get and how they would be protected remains W. McFeely, Yanke Stepfather: General O.O. Howard and the Freedmen (1968).

87. L. CoX, supra note 82, at 75-111; W. MCFEELY, supra note 86, at 169-70.

88. Sherman's plan for the Sea Islands and the southeastern coastline was rescinded when Treasury Department officials won this particular bureaucratic turf battle with the military on the grounds that the redistribution would have constituted theft from the Confederate owners. See, e.g., L. Cox, supra note 82, at 27-28; L. Gerteis, From Contraband to Freedman: Federal Policy Toward Southern Blacks, 1861-1865, at 153-92 (1973); D. Nieman, To SET the LAw IN Motion: The Freedmen's BuReaU and THe Legal Rights of BLACKS, 1865-1868, at 11-12, 65 (1979) (inadequate personnel to control contract abuses or to protect black workers against violence of planters and imposition of terms of Black Codes despite federal invalidation); W.L. Rose, supra note 68, at 346-77; May, Continuity and Change in the Labor Program of the Union Army and the Freedmen's Bureau, 17 Crvil WAR HIST. 245 (1971).

89. H. TREFousse, supra note 36, at 282; see also L. Cox, supra note 82, at 25-26 (calling Lincoln "paternal but not paternalistic" in his long-term focus on "economic concept of free society").

90. The prohibition against taking from $A$ to give to $B$ has often been characterized as one of the clearest restrictions on government. See, e.g., Loan Ass'n v. City of Topeka, 87 U.S. (20 Wall.) 655, 662-63 (1875); Calder v. Bull, 3 U.S. (3 Dall.) 386, 388 (1798) (Chase, J.). But as Morton Horwitz points out, even in the antebellum period people often went to law to mask subsidies or transfers of property. M. HoRwITz, supra note 54, at 99-101. The Thirteenth Amendment undeniably altered the property rights of Southerners without compensating them.

91. See, e.g., Weiner, Higgs \& Woodman, Class Structure and Economic Development in the American South, 1865-1955, 84 AM. Hist. REv. 970 (1979) (colloquy on sharecropping debate). Compate J. Mandle, The Roots of Black Poverty: The Southern Plantation Economy AFTER the Givil War (1978); R. RanSom \& R. Sutch, ONe Kind of FreEdom: The Economic Consequences of Emancipation (1977) and G. Wright, The Political Economy of the Cotton South (1978) with S. DeCanio, Agriculture in the Postbellum South (1974) and R. Higgs, Competition and Coercion: Blacks in the American Economy, 1868-1914 (1977). For discussion of lost opportunities and the suppression of efforts by blacks to organize in the half century after emancipation, see W. Harris, The Harder We RuN: BlaCk Workers Since THE Crvil WAR 7-50 (1982); Roback, Southern Labor Law in the Jim Crow Era: Exploitative or Competitive?, 51 U. Chi. L. REv. 1161 (1984).

92. L. Litwack, Been In the Storm So Long: The Aftermath of Stavery (1979). 
cial reality at the end of the storm of slavery ${ }^{93}$-we can more fully appreciate the difficulty as well as the hope that emancipation entailed. Yet we have little work on law in the trenches during the period, ${ }^{94}$ and scarcely any attention has been paid to the effect of old contract law on the new status of freedmen.

The legal situation in the South at the end of the Civil War was a chaotic blend of old and quickly emerging doctrines in the "private law" realms of property and contract law. ${ }^{95}$ The federal government interposed an unprecedented administrative mechanism, staffed by the military, which soon collapsed into the sort of bureaucratic wrangling all too familiar to the modern eye. A sharp tension developed between the residual folkways of slavery and the new, vastly different ideas of what post-war legal freedom entailed. ${ }^{96}$ Soon savage armed resistance emerged to challenge the brief attempt to use national "public" law as an instrument for the liberation of four million slaves. ${ }^{97}$

These multiple layers of law present internal contradictions and intractable difficulties. A neat, pyramidal structure simply did not exist in the legal culture; constitutional law was not perched atop the legal order. After the war, the most private and individualistic legal categories seemed quickly and convincingly to overcome all others. ${ }^{88}$ Contract law triumphed

93. See, e.g., L. Powell, New Masters: Northern Planters During the Givil War and RECONSTRUCTION (1980); J. ROARK, supra note 52, at 196-209. For a recent documentary history, which also contains fine descriptive essays, see 1 I. BERLIN, B. FIELdS, T. Glymph, J. ReIdy \& L. Rowland, FreEdom: A Documentary History of EMancipation, 1861-1865 (1985). The best example of a local study is still probably J. Williamson, AfTER Slavery: The Negro IN SOUTH Carolina During Reconstruction (1963), now supplemented by J. Williamson, The Crucible of Race: Black-White Relations in the American South Since Emancipation (1984) [hereinafter J. Williamson, The Grucible of RACE] (analyzing violent mix of race, sex, and class in Southern "mentality"); see also E. Foner, The Emancipated Worker, in NotHING BuT FREEDOM: EMANICPATION AND ITS LEGACY 74-110 (1983) (study of 1876 strikes on rice plantations in South Carolina). For a good compilation of local studies, see RECONSTRUCTION AND REDEMPTION IN THE SouTh (L. Olsen ed. 1980). For general historiography, see Cohen, Negro Involuntrary Servitude in the South, 1865 1940: A Preliminary Analysis, 42 J.S. Hist. 31 (1976); Woodman, Seguel to Slavery: The New History Views the Postbellum South, 43 J.S. Hist. 523 (1977).

94. But see E. Ayers, supra note 51, at 141-222; Hall, Political Power and Constitutional Legitimacy: The South Carolina Ku Klux Klan Trials, 1871-72, 33 Emory L.J. 921 (1984); Haws \& Namorato, Race, Property Rights, and the Economic Consequences of Reconstruction: A Case Study, 32 VAND. L. Rev. 305 (1979); Westwood, Getting Justice for the Freedman, 16 How. L.J. 492 (1971).

95. See, e.g., L. LrTwsck, supra note 92, at 408-25 (1979) (discussing substance of contracts between freedmen and whites in South and attitudes of southern freedmen and whites to those contracts); D. NiEMAN, supra note 88 , at $97-98,161-71$ (Bureau officials unable to regulate local affairs to protect freedman).

96. See L. LiTwACK, supra note 92 , at 336-49.

97. See, e.g., E. Ayers, supra note 51, at 142-65; J. Williamson, The Crucible of Race, supra note 93, at 19-35; B. WyatT-Brown, Southern HoNOR: ETHICs AND DishoNor IN THE Old South 453-61 (1982). See generally A. Trelease, White Terror: The Ku Kuux ConspirACY AND SOUTHERN RECONSTRUCTION (1971) (fine overview of role of Klan).

98. Compare Scott v. State, $39 \mathrm{Ga} .321$ (1869) (upholding segregation and prohibition against miscegenation as valid legislative regulations of social status and "civil contract") with Williams v. 
in the legal imagination and permeated popular belief. The "grand yet simple declaration of universal freedom" set out in the Thirteenth Amendment, and elaborated in the first section of the 1866 Civil Rights Act, ${ }^{100}$ appeared overly intrusive, nationalistic, unsettling, and perhaps old-fashioned. It was the era of Horatio Alger characters and of Thomas M. Cooley's limitations on government. ${ }^{101}$ It was the heyday of contract's presumed free meeting of the minds. ${ }^{102}$

Simple survival was excrutiatingly difficult in the South just after Appomattox. The stricken Southern economy grew even worse in the following years. As credit virtually disappeared, Confederate money lost all value, land prices plunged, an already severe labor shortage worsened, and unusually bad weather caused crop failures in 1866 and $1867 .{ }^{103}$

Waters, $36 \mathrm{Ga} .454$ (1867) (enforcing contract after holding that parol evidence rule barred oral testimony by illiterate sharecropper and holding that it was sufficient that Bureau officials and judges had read contract-which seems excessively favorable to landowner-to sharecropper, and that landowner could testify about disappointing crops) and Comas v. Reddish, $35 \mathrm{Ga}$. 236 (1866) (warning public functionaries to "be vigilant in preventing any one, under the name of master, from getting the control of the labor and services of . . . [a] minor apprentice, as if he were still a slave."). The South Carolina courts were considerably more conservative, insisting that the Emancipation Proclamation had no legal effect, since "[t]he President had not the right to make them free." Pickett v. Wilkins, 13 S.C. Eq. (13 Rich. Eq.) 366, 367 (1866) (partition of estate executed in 1864 valid, even though some heirs received only slaves); see also Bailey v. Greenville \& C.R.R., 2 S.C. 312 (1870) (one who hired slaves from owner must pay owner whether or not slaves were liberated by Emancipation Proclamation); Calhoun v. Calhoun, 2 S.C. 283, 306-07 (1870) (enforcing payment of debts involving slaves prior to emancipation not against public policy); Burgess v. Carpenter, 2 S.C. 7, 10 (1870) (black sharecropper a co-partner, not servant, so he was "sui juris" and could not sue owner of land for his injury).

99. Slaughter-House Cases, 83 U.S. (16 Wall.) 36, 69 (1873).

100. Civil Rights Act of 1866 , ch. $31, \S 1,14$ Stat. 27 (current version at 42 U.S.C. $\S \S 1981-1982$ (1982)).

101. The first Horatio Alger novel in the Ragged Dick series was published in 1868, see E. Hoyt, Horatio's Boys: The Life and Works of Horatio Alger, JR. 74-84 (1974), the same year Judge Cooley first published his A Treatise on the Constrtutional Limitations Which Rest upon the Legislative Power of the States of the American Union (Boston 1868). Cooley's title was less snappy, but his book's influence may have been as great. See, e.g., C. JACOBS, Law Writers and the Courts: The Ineluence of Thomas M. Cooley, Christopher G. Tiedeman and John F. Dillon Upon American Constitutional. Law 128, 151-52 (1954); B. Twiss, Lawyers and the Constitution: How Laissez Faire Came to the Supreme Court 18-41 (1942). See generally S. Fine, Laissez Faire and tHe General-Welfare State: A Study of Conflict IN AMERICAN Thought, 1865-1901, at 128-29, 142-43 (1956) (discussing Cooley's influence on the development of laissez-faire constitutionalism); P. PALudan, supra note 14, at 249-73 (biographical chapter on Cooley).

102. See, e.g., S. FINE, supra note 101, at 56-73 (impact of laissez-faire economists in postbellum period); G. Gilmore, THE Ages of AMERICAN LAw, supra note 54, at 46-67 (formalism during legal "Age of Faith"); B. Twiss, supra note 101, at 18-62 (use of radical individualism by lawyers and judges). For a largely parallel description of doctrinal developments in England, see P. ATIYAH, supra note 57, at 388-97, 671 (formalization of contract and demise of equity). Litwack observes that "Freedmen's Bureau officers and northern white missionaries and teachers advanced the classic midnineteenth century self-help ideology," L. LITwACK, supra note 92, at 403. As one Bureau commissioner in Mississippi scolded the former slaves, "[y]our contracts were explained to you, and their sacredness impressed upon you, again and again." Id. at 409.

103. W. MCFEELy, supra note 86 , at 162 ; J. RoARK, supra note 52 , at $148,170-80$; sources cited supra note 91. 
Contract law began to fill some of the gap created by the abrupt termination of the hierarchical status relationships of the antebellum period.

Paradoxically, when many former masters and slaves declined to enter into voluntary contracts with one another, the Freedmen's Bureau forced them into "contractual" relationships. General Banks had imposed a mandatory year-long contract scheme in occupied Louisiana during the war. The Bureau officials developed variations on the theme, stressing order rather than consent. ${ }^{104}$ Though direct evidence of extralegal dispute settlement is sparse, we have strong reason to believe that resistance was far more widespread than Bureau reports indicate. ${ }^{105}$ For example, planters formed local associations to resist contracts with freedmen altogether, or to hold down wage scales by agreeing not to bid for labor. ${ }^{106}$ When former slaves learned that their claims to own the land they had worked and watered with the sweat of their brows would not be honored ${ }^{107}$ some wandered off or appropriated the farm animals they had cared for and believed they now could legitimately claim. ${ }^{108}$ If blacks publicly dared to

104. In Louisiana, Banks used military marshals to enforce penalties for disobedience and laziness; idleness was a crime. The plan included a wage scale and had a maximum hour provision; it also guaranteed rations, schooling, and medical care. See H. BELz, supra note 63, at 45-46, 96; May, supra note 88, at 250-51. Litwack describes in vivid detail the contract enforcement approach of many Freedmen's Bureau officers. L. LrTwACK, supra note 92, at 284-85, 408-28. In significant ways, the Freedmen's Bureau and its failures represent a stage of nascent federal bureaucracy, though the magnitude of its task and the limitations and shortcomings of the military personnel it employed made its job unusually difficult.

105. L. Gerteis, supra note 88, at 190-91 (officers of severely undermanned Bureau ordered not to arrest whites charged by blacks unless "proof is clear" in "serious criminal cases"); W. McFeELY, supra note 86, at 211-66, 273-87 (detailing bitter internal divisions within Bureau and Bureau's inability to deal with starvation, to prosecute individual white murderers, or to control rioting against blacks); L. LrrwACK, supra note 92, at 284 (Freedmen's Bureau seldom intervened in legal matters, though it had the power to do so, and thus "revealed more about the predilections of Bureau officers than the impartiality of civil justice").

106. D. NiEmAN, supra note 88, at 97-98, 172-75 (laws passed and administered after the Civil Rights Act of 1866 invalidated Black Codes still imposed harsher penalties on blacks, punished vagrancy severely, and forbade enticing blacks from year-long employment contracts); L. LrTwACK, supra note 92, at 415-16 (white planters formed combinations and used violence to control wages, ability of blacks to lease land, and other aspects of contracts).

107. W. McFeELY, supra note 86, provides the most powerful description of the end of the promise of land, including the spectacle of Bureau officials driving blacks off land they had worked throughout the Civil War which they were led to believe was theirs. McFeely also describes the willingness of O.O. Howard, at the end of his tenure as head of the Bureau, to help recruit blacks for labor gangs. Though Howard was "an exemplary nineteenth-century American," McFeely notes, "[b]y not speaking up, Howard contributed immensely at a critical moment to the process-in the end it defeated Reconstruction-by which the nation pulled the wool over its eyes with respect to the freedmen." Id. at $310,315$.

108. L. LrTwACK, supra note 92 , at 392,398 , notes that though the dispossessed slaveholders thought themselves entitled to compensation, "the question of remunerating the slaves for black labor never reached serious consideration." Litwack suggests that it is surprising that so few blacks appropriated what they had toiled to produce, and that "the readiness of Federal authorities to back up the legal claims of whites to their land" helps explain the phenomenon. Id. at 212. Moreover, since the death of slavery proved so slow, and the progress of the war in any locale so unpredictable, Litwack's book is full of human dramas involving the independence and dependence of slaves and masters set against the backdrop of almost unfathomable possibilities of military intervention. 
stand on their new legal rights, whites frequently responded with brutal violence. These "dispute settlements" were sometimes reported to, but virtually never controlled by, the personnel of the grossly understaffed Freedmen's Bureau. ${ }^{108}$

After Appomattox, the former slaves had been given their freedom in the eyes of most Americans; they were freedmen and not free men. Under the tutelage of overburdened and often unsympathetic army officers, blacks soon learned firsthand of the formal, binding nature of contracts. ${ }^{110}$ They had precious little autonomy and soon found their responsibility under the year-long contracts they were required to sign, contracts binding them to the land until they paid off the credit advanced for seed and supplies, to be remarkably reminiscent of slavery. Freedmen's Bureau officials, anxious to get the South back to work, often functioned as replacements and functional equivalents for the overseers whose job description had been formally eliminated by emancipation. ${ }^{111}$

Unrealistic presumptions of equal bargaining power prevailed in both private and public legal realms. When we cast aside the doctrinal baggage of those presumptions, however, we begin to see that the hegemony of these presumptions may not have been inevitable. The contemporary law of labor contracts remained distinct from the main body of contract law; its special rules for special cases-for sailors and women, for example $^{112}$ - belied appeals to a universal legal science of contracts. The dominant rubric in these areas remained master-servant law, replete with a host of accompanying paternalistic assumptions and exceptions. ${ }^{113}$

109. See generally W. MCFeEly, supra note 86, at 149-65; D. Nieman, supra note 88 , at 133-47, 177-90, 209-16.

110. See, e.g., L. LITwACK, supra note 92, at 336-86 (poignant details of chaotic postemancipation world and of army officers' cooperation in system of "constructive compulsion"). The New Orleans Tribune compared the "mitigated bondage" of the "mock freedmen" to Russian serfdom. See id. at 377. Litwack summarizes the parallels between sharecropping and slavery as follows:

Established to ease the ex-slaves' transition to freedom, the Freedmen's Bureau ultimately facilitated the restoration of black labor to the control of those who had previously owned them. . . . [E]ven the best-intentioned of the commissioners and local agents manifested their sympathy for the freedmen in curious and contradictory ways, embracing a paternalism and a contract labor system that could only perpetuate the economic dependency of the great mass of former slaves.

Id. at 386; see also J. Jones, LABOR of Love, LABor of SORRow: Black Women, Work, AND THE FAMIly fRom SLAvery to THE PRESENT (1985) (black wives and mothers forced to work outside homes for family subsistence).

111. See supra notes $98-109$ and accompanying text.

112. Enthusiasm for drawing clear lines between separate classes or spheres was a crucial component in the legal culture throughout the nineteenth century, but this tendency increased in the postbellum period. See supra notes 37, 101, 102, and accompanying text. The law of persons was the fount for systematic manipulation of those categories. See, e.g., N. BASCH, supra note 40; L. FRIEDMAN, supra note 43; Kay, The Equal Protection Clause of the Supreme Court, 1873-1903, 29 Buffalo L. REv. 667 (1980) (Justices assumed formal equality and invalidated "class" legislation).

113. See, e.g., T. Bishop, Commentaries on the Non-Contract Law chs. 31-32 (1889) ("Master and Servant"; "The Master's Duties and Liabilities to the Servant, Fellow Servants"); G. 
Many Americans decried governmental intrusion as they hastened to put the war behind them and to resume the economic race of life. President Andrew Johnson's controversial February 1866 veto message concerning the Freedmen's Bureau Bill illustrated a new emphasis on avoiding paternalism at almost all costs, and certainly at the cost of protecting the freedmen. Johnson claimed that the bill would discriminate against "millions of the white race, who are honestly toiling from day to day for their subsistence."114 Indeed, although the President purported to support the freedmen in "their entire independence and equality in making contracts for their labor," ${ }^{118}$ he adamantly rejected any role for the federal government in guaranteeing these rights. The freedmen, according to Johnson, had to establish and support "their own asylums and schools." ${ }^{116}$ To Johnson, the race of life for former slaves was underway; the national government had done enough already.

Johnson looked backward, in his faith in states' rights, and forward, in his faith in economic competition without governmental regulation. Tragically, his states' rights and free market views anticipated the future more accurately than did his congressional opponents. For a brief historical moment, however, Johnson's views did not prevail. After the Senate failed by a single vote to override Johnson's veto of the Freedmen's Bureau Bill, ${ }^{112}$ Congress succeeded in narrowly overriding Johnson's veto of a Givil Rights Act also written by Senator Trumbull. In that April, 1866 Act, Congress emphasized both its sense that the Thirteenth Amendment empowered the federal government to enforce a long list of civil rights and its willingness to use the machinery of the federal government, including but

Gilmore, The Death of Contract, supra note 54, at 3-34; S. Hollungsworth, A Treatise ON THE LAW OF CONTracts 124-26, 188-94 (1896) (discussing consideration and limited notions of duress); T. Metcalf, Principles of the Law of Contracts as Applied By Courts of Law ch. 2 (1878) (subdividing parties to contracts and emphasizing that consideration need not be adequate); Forbath, The Ambiguities of Free Labor: Labor and the Law in the Gilded Age, 1985 WIS. L. REv. 767; Gordon, Legal Thought and Legal Enterprise in the Age of American Enterprise, 1870-1920, in Professions ANd Professional Ideologies in America, 1970-1920, at 70-110 (G. Gieson ed. 1983); Hurvitz, American Labor Law and the Doctrine of Entrepreneurial Property Rights: Boycotts, Courts, and the Juridical Reorientation of 1886-1895, 8 IND. REL. L.J. 307, 309-21 (1986); Lieber, The Supreme Court on the Military Status, 31 AM. L. REv. 342, 353 (1897).

114. See Cong. Globe, 39 Cong., 1st Sess. 1679-80 (1866). His message was drafted by the historian George Bancroft and attempted to refute the broad nationalistic basis of the bill, drafted by Senator Trumbull with the aid of General O.O. Howard. Cox \& Cox, Andrew Johnson and His Ghost Writers: An Analysis of the Freedmen's Bureau and Civil Rights Veto Messages, 48 Miss. VALLEY HIST. REv. 460, 469-73 (1961).

115. Cox \& Cox, supra note 114 , at 469.

116. Id. For discussion of Johnson's views generally and the powerful effect they had in pushing Moderate Republicans into the waiting arms of Radical Republicans, see Soifer, supra note 51, at 690-96.

117. See W. Brock, An American Grisis: Congressional Reconstruction, 1865-1867, at 106 (1963). 
not limited to the federal courts, to guarantee "full and equal benefit of all laws and proceedings." $" 118$

The nearly complete failure of this guarantee over the next century-though the Fourteenth Amendment ${ }^{119}$ removed any doubts as to its constitutionality-typifies the American legal system's resistance to change. Congress may have doomed the protection of equal rights it championed in the abstract by delegating enforcement of the Civil Rights Act of 1866 to federal courts, where judges could apply their notions of scientific contract law. ${ }^{120}$

Perhaps the best illustration of the bankruptcy of the law's bequest to former slaves is the uncompensated loss of their savings when the Freedmen's Savings Bank failed soon after the Panic of $1873 .{ }^{121}$ The former slaves had been barraged with propaganda to become self-made men by means of saving every hard-earned penny. Now, despite repeated reassurances to the contrary, ${ }^{122}$ they discovered that the federal government did

118. Civil Rights Act of 1866 , ch. $31, \S 1,14$ Stat. 27 (current version at 42 U.S.C. $\S \S 1981-1982$ (1982)). The Act guaranteed to

all persons born in the United States and not subject to any foreign power, excluding Indians not taxed . . . the same right, in every State and Territory in the United States, to make and enforce contracts, . . . and to full and equal benefit of all laws and proceedings for the security of person and property, as is enjoyed by white citizens.

Id.; see Cong. Globe, 39th Cong., 1st Sess. 1857 (1866).

119. Congress' view that the Fourteenth Amendment would eliminate any doubt about the constitutionality of the 1866 Civil Rights Act is one of the few points of widespread agreement in the ongoing debate analyzing the enactment and ratification of the Fourteenth Amendment. See, e.g., R. Berger, Goverment By Judiciary 99-116 (1977); H. Flack, The ADoption of the FourTEENTH AMENDMENT 136-39, 210-77 (1908). Despite repassage of the 1866 Civil Rights Act in haec verba in the Enforcement Act of 1870 , ch. 114, $\$ 16,16$ Stat. 140 (current version at 42 U.S.C. $\$ \S 1981-1982$ (1982)), there is new controversy over whether the protection of the Civil Rights Act extends as far as its language seems to state. See 55 U.S.L.W. 3579-81 (U.S. Mar. 3, 1987) (reporting Supreme Court oral arguments in Shaare Tefila Congregation v. Cobb (No. 85-2158) and Saint Francis College v. Al-Khazraji (No. 85-2169)).

120. See, e.g., Gelpcke v. City of Dubuque, 68 U.S. (1 Wall.) 175, 206-07 (1864) ("We shall never immolate truth, justice, and the law, because a State tribunal has erected the altar and decreed the sacrifice."). For a description of the expansive judicial view of federal common law jurisdiction after the Civil War, see T. Freyer, Harmony and Dissonance: The Swift and Erie Cases IN AMERICAN FEDERALISM (1981). As Perry Miller pointed out, lawyers and judges have long found it convenient to proclaim a special science of the law. See P. Miller, The Life of THE Mind IN America From the Revolution to the Civil WAR 156-85 (1965); see also Chase, The Birth of the Modern Law School, 23 AM. J. LEGAL. HIST. 329 (1979) (arguing that Charles Eliot, using chemistry laboratory model, was primarily responsible for case method, not Langdell); Grey, Langdell's Orthodoxy, 45 U. PITT. L. REv. 1 (1983) (tracing classical orthodoxy in legal thought to principles of geometry).

121. See W. Fleming, The Freedmen's Savings Bank (1927); C. Osthaus, Freedmen, Phi-

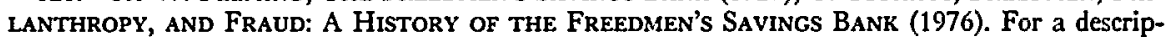
tion of the general movement during the period from active governmental intervention immediately after the war towards governmental passivity across a broad range of activities, see M. KELLER, Affairs of State: Public Life in Late Nineteenth Century america 34 (1977).

122. For an excellent account of the causes and consequences of the Freedmen's Savings Bank failure, see C. Osthaus, supra note 121, at 173-225. Though he acknowledges that the Bank "had no monopoly on ignorance, speculation, fraud, or tragedy," Osthaus makes clear that "the losses of the Bank were among the worst of that decade-and all the more tragic because they were the first 
not stand behind the bank it set up for them. Compounding the poignancy of the collapse was the presence of Frederick Douglass as president, a post he had been maneuvered into just before the bank's demise. ${ }^{123}$ But in the immediate post-war years, Congress determined repeatedly not to leave the former slaves alone.

Congress vastly increased federal court jurisdiction and repeatedly enacted federal measures to protect civil and ultimately political rights across the nation. ${ }^{124}$ Moderates also allied with many Radicals in their desire to keep the freedmen in the South, and to respond to the threat of increased congressional power for the South now that blacks counted as full persons for purposes of calculating representation. Vindictiveness towards the South and a powerful desire to ennoble those who died by denying the South any of the fruits of the Union victory also animated some post-war political alliances. By 1867, Congress deemed the South unwilling or unable to protect black citizens; Congress carved out five military districts and again sent in the army. ${ }^{225}$

But daily life soon triumphed over legal promises promulgated hundreds of miles away. The chaos of war and the political and legal battles of early Reconstruction gave way to renewed faith in the purported symmetries of private law as the infrastructure of social order. In particular, the legal faith of the Gilded Age rested primarily on contract law and its formal assumptions about free will.

By 1871 , federal courts were expanding their federal common law powers under a latitudinarian interpretation of Swift v. Tyson ${ }^{\mathbf{1 2 B}}$ to enforce private obligations, even if those obligations were incurred in the course of buying and selling slaves. ${ }^{127}$ Thus, in the same year that Christopher Co-

savings of a recently freed people, symbolizing hopes for equal citizenship and economic security." Id. at 200. Those losses were never repaid; the only congressional responses to numerous freedmen's petitions "pleading that the government assume the company's assets and pay immediately the amounts due them" were two investigations of the Bank which revealed that the Bank "had been little more than an enormous swindle" and a few bills to reimburse the depositors, none of which led to legislation. Id. at 208, 215-21. Compounding the tragedy was the fact that the Freedmen's Savings Bank had constantly played upon its closeness with the Bureau and linked itself to national figures such as Generals Grant, Sherman and Howard, and to President Lincoln in advertising and deposit books. As Osthaus states, "the symbols of freedom had become the symbols of bank safety." Id. at 55 . Moreover, depositing their funds in the bank was a part of the payday ritual for black soldiers and for other blacks who responded to repeated importuning that they had to be thrifty in order to get ahead. Id. at $26-33,87$.

123. Id. at $186-98$.

124. See H. BELZ, supra note 63, at 157-77; H. HyMAN supra note 79, at 414-45; Soifer, supra note 51 , at $670-96$.

125. Military Reconstruction Act of Mar. 2, 1867, ch. 153, 14 Stat. 428.

126. 41 U.S. (16 Pet.) 1 (1842); see T. FREYER, supra note 120, at 41-100.

127. Osborn v. Nicholson, 80 U.S. (13 Wall.) 654, 663 (1871) ("Whatever we may think of the institution of slavery viewed in the light of religion, morals, humanity, or a sound political economy-as the obligation here in question was valid when executed, sitting as a court of justice, we have no choice but to give it effect."); White v. Hart, 80 U.S. (13 Wall.) 646, 653 (1871) ("The ideas of 
lumbus Langdell introduced the case method at Harvard and began the quest in contracts cases for "Law, considered as a science," the Supreme Court determined that federal common law prohibited the Louisiana legislature from voiding sales contracts for slaves. ${ }^{128}$ Faith in perceived principles of contract law was even more evident in 1875, when Justice Swayne, writing for a unanimous Court, tried to "roll back the tide of time, and to imagine [him]self back in Mississippi before abolition."128 Having accomplished this feat, Swayne defeated a black man's contractual claim to a share in the cotton crop produced on the plantation where he toiled. ${ }^{130}$ Even accepting the truth of the former slave's account, Justice Swayne reasoned, slaves could not contract in Mississippi at that time as a matter of law. Accordingly, the Court held that the former slave clearly had no legal claim. ${ }^{131}$

This was also, of course, the ignominious period when the Court enthusiastically eviscerated the federal civil rights statutes, ${ }^{\mathbf{1 3 2}}$ effectively nulli-

validity and remedy are inseparable and both are parts of the obligation which is guaranteed by the Constitution against invasion.").

128. This formal notion of the obligation of contracts contrasts with an earlier view that courts should consider the morality of the underlying contract, as in Greenwood v. Curtis, 6 Mass. 358, 365-66 (1810) (Sedgwick, J., dissenting). The Essex Result of 1778, for example, stated: "Thus, if a man surrender all his alienable rights, without reserving a controul over the supreme power, or a right to resume in certain cases, the surrender is void, for he becomes a slave; and a slave can receive no equivalent. Common equity would set aside this bargain." The Popular Sources OF Political AUthoRITY: Documents ON THE MASSAChuSETTS Constitution of 1780, at 324, 330 (O. Handlin \& M. Handlin eds. 1966). See generally P. ATrYaH, supra note 57, at 460-93, 671; M. HoRwrTz, supra note 54 , at $173-85$. In the introduction to his famous casebook, Langdell stated:

Law, considered as a science, consists of certain principles or doctrines. To have such a mastery of these as to be able to apply them with constant facility and certainty to the ever-tangled skein of human affairs, is what constitutes a true lawyer; and hence to acquire that mastery should be the business of every earnest student of law. Each of these doctrines has arrived at its present state by slow degrees; in other words, it is a growth, extending in many cases through centuries.

C.C. Langdell, Law of Contracts vi (1871).

In this spirit of labored attention to established principles, coupled with a desire to expand federal jurisdiction to control state legislatures, the Supreme Court in the post-Civil War years went well beyond the holding of Swift $v$. Tyson in stretching diversity jurisdiction. Thus, for example, the Justices were no longer deterred if the state law they ignored in a diversity case involved state legislation rather than a judicial declaration of the law. The Justices, probably because they so abhorred the actions of southern reconstruction legislatures, showed no timidity in reaching to void state laws, state constitutional provisions, and state judicial decisions that declared all contracts for the sale of slaves against public policy and therefore no longer binding. See, e.g., Osborn v. Nicholson, 80 U.S. (13 Wall.) 654 (1871) (neither Thirteenth Amendment nor section 2 of Fourteenth Amendment barring compensation for slaves voided pre-war contract to buy slave); White v. Hart, 80 U.S. (13 Wall.) 646 (1871) (new state constitution could not affect contract, even though contractual consideration was slave).

129. Hall v. United States, 92 U.S. 27, 30 (1875).

130. The Court discussed how Hall's color was presumptive proof of his bondage, as well as the general harshness of the law of African slavery. Id. at 28.

131. Id. at 30. The Court emphasized that if the former slave did contract with his owner, "the contract was an utter nullity. In the view of the law, it created no obligation, and conferred no rights as to either of the parties."

132. See, e.g., United States v. Cruikshank, 92 U.S. 542 (1876) (applying doctrine of the Slaugh- 
fied the privileges or immunities clause of the Fourteenth Amendment, ${ }^{133}$ and imposed a newly-minted "state action" requirement ${ }^{\mathbf{1 3 4}}$ to ensure that regulation of private law matters such as contracts would be left solely to the states. Moreover, state courts had shown increasing enthusiasm for perceived constitutional commands of liberty of contract, and the courts were soon joined by the Supreme Court. Judge Cooley's influential treatise advocating implicit constitutional limits on federal and state governments, combined with Langdell's thrust toward legal formalism, lent respectability to the judiciary's rout of civil rights. ${ }^{138}$ Together, the work of

ter-House Cases to dismiss a complaint brought by two black men under $\S 6$ of Enforcement Act for interference with their right to vote); United States v. Reese, 92 U.S. 214 (1876) (holding that $\S \S 3$ and 4 of Enforcement Act of 1870, which provided for criminal prosecutions of officials who obstructed citizens from qualifying for voting, were not warranted by Fifteenth Amendment and thus unconstitutional); see also Hall v. DeCuir, 95 U.S. 485 (1877) (invalidating, on dormant commerce clause grounds, Reconstruction-era Louisiana statute prohibiting common carriers of passengers from discriminating on basis of race or color). See generally 2 C. FAIRMAN, ReCONSTruction AND REUNION, 1864-88, at 221-89 (1987) (vol. seven of Holmes Devise History of the Supreme Court of the United States); Waite, The Negro in the Supreme Court, 30 Mins. L. REv. 225, 230-37 (1946) (discussing Chief Justice Waite's opinions in Reese, Cruikshank, and Hall).

133. See Slaughter-House Cases, 83 U.S. (16 Wall.) 36, 37-38 (1873). Justice Miller's opinion for a sharply-divided Court demolished the privileges or immunities clause of the Fourteenth Amendment by suggesting a basic division between state and federal citizenship that the majority considered to be fundamentally unaltered by the post-Civil War amendments. Even Miller, however, conceded that the Thirteenth and Fourteenth Amendments provided "additional guarantees of human rights; additional powers to the Federal government; additional restraints upon those of the States." Id. at 67-68.

134. In The Givil Rights Cases, 109 U.S. 3, 18-19 (1883), Justice Bradley's majority opinion held the Civil Rights Act of 1875, ch. 114, 18 Stat. 335, unconstitutional, because it attempted to use federal authority to guarantec "full and equal enjoyment" of public accommodations. The basis for the Court's opinion was its view, obviously not shared by Congress or President Grant, that a federal act goes too far when it "steps into the domain of local jurisprudence, and lays down rules for the conduct of individuals in society towards each other, and imposes sanctions for the enforcement of those rules, without referring in any manner to any supposed action of the State or its authority." 109 U.S. at 14. Through its failure to enforce the Civil Rights Act of 1875 vigorously-part of a general lack of will to stop the southern "revolution of 1875," W. MCFEELY, GRANT 418-25 (1981)-the federal government anticipated the Great Betrayal that resolved the 1877 presidential election and ended Reconstruction.

Justice Bradley did note that the Thirteenth Amendment "clothes Congress with power to pass all laws necessary and proper for abolishing all badges and incidents of slavery in the United States." 109 U.S. at 20. His opinion quickly moved, however, to a classic slippery slope argument contained within a single important sentence. Justice Bradley conflated private action with less private action and then with decisions about access to public accommodations and to "other matters of intercourse or business." Id. at 24-25. Bradley's crucial sentence was: "It would be running the slavery argument into the ground to make it apply to every act of discrimination which a person may see fit to make as to the guests he will entertain, or as to the people he will take into his coach or cab or car, or admit to his concert or theatre, or deal with in other matters of intercourse or business." Of course, I do not claim to have had the final word on the vexing issues of state action and the Thirteenth Amendment in my essay reviewing Raoul Berger's book, supra note 51. See, e.g., Chemerinsky, Rethinking State Action, 80 Nw. U. L. Rev. 503 (1985), and the response and rebuttal that follow; Dimond, Strict Construction and Judicial Review of Racial Discrimination Under the Equal Protection Clause, 80 Mich. L. REv. 462 (1982). But readers can evaluate my argument by reading it along with Berger's reply in Berger, Soifer to the Rescue of History, 32 S.C.L. REv. 427 (1981).

135. See sources cited supra note 101; E. Corwin, The Twilight of the Supreme Court: A History of Our Constitutional Theory (1934); A. Paul, Conservative Crisis and the Role of Law: Atrtrudes of BAR AND BENCH, 1887-1895 (1960); Hamilton, Freedom of Con- 
federal and state courts provided a fitting culmination to the "years of contract."

As with most culminations, however, this was also the beginning of the end. Liberty of contract had come to dominate constitutional law in part because legislatures had begun to challenge the exclusivity of judicial regulation of private contracts. ${ }^{136}$ Still, the language of clear, binary legal categories dominated the rhetoric of treatises and appellate judges in the last quarter of the century even more than it usually does. Judges emphasized that choices between liberty and paternalism were either/or matters of principle. The reality of the sharecropper's bargaining position, whether he was black or white, had no place in the legal categories through which appellate judges enforced their own views about government regulation of the natural struggle of life. ${ }^{137}$

A kind of deep structure of belief in states' rights and state sovereignty was an essential factor in the failure of Reconstruction. ${ }^{138}$ In resorting to contract law to establish a new status for freedmen, Congress invited judges to exercise discretion. Through the use of hoary legal principles about contractual autonomy, these judges returned black workers almost to the status quo ante bellum. Ironically, as Jack Dawson demonstrated a half-century ago, this outcome could have been avoided. Southern judges possessed, and routinely used, tremendous discretionary power in contract cases after the war. ${ }^{139}$

The Thirteenth Amendment was soon irrelevant to everything but the most overt physical constraint. ${ }^{140}$ Judges, perhaps more than most people,

tract, in 3 Encyclopedia of THE Social Sciences 450 (1931); Kennedy, Form and Substance in Private Law Adjudication, 89 HARv. L. Rev. 1685 (1976).

136. See Pound, Liberty of Contract, 18 YALE L.J. 454, 455, 471 (1909); Soifer, supra note 37, at $258-60,274-77$.

137. S. FiNe, supra note 101, at 160-61; Soifer, supra note 37 , at 260-74.

138. See; M. BENEdict, supra note 74 ; H. HYMAN, supra note 79 , at 434-41; P. PALUdAN, supra note 14, at 49-54; see also R. Kaczorowski, The Politics OF Judicial INTERPRETation (1985); S. Kutler, Judicial Power and Reconstruction Politics (1968).

139. In 1934 and 1935, John P. Dawson wrote or co-authored four articles in Volume 33 of the Michigan Law Review dealing with the problems of inflation and currency regulation. Dawson's work, which has generally been overlooked by historians, is a treasure-trove of information and of provocative insight. The article most relevant to the present discussion, written with Frank E. Cooper, is The Effect of Inflation on Private Contracts: United States, 1861-1879 (pts. 1 \& 2), 33 MICH. L. Rev. 706, 852 (1935) ("Confederate Cases" and "Northern Cases," respectively). Charles Fairman provides incomparable detail on the struggle between state and federal courts over the related, largely successful effort of southern states to avoid enforcement of bond obligations in 1 C. FAIRMAN, supra note 132. For an excellent recent study of the successful use of the Eleventh Amendment by the Southern states (except Virginia) to evade their bond obligations, see J. ORTH, THE JUdicial Power of the United States: The Eleventh Amendment in American History (1987).

140. In Clyatt v. United States, 197 U.S. 207 (1905), for example, Justice Brewer's majority opinion invalidated one of the rare successful peonage prosecutions, the conviction by a jury of a brutal white overseer in the south Georgia and Florida turpentine farms. Brewer emphasized that debt was the necessary "basal" condition of compulsory service and therefore held that, since no peon was indebted to the master, the case should not have gone to the jury. Id. at 215 . For the factual 
value order. In the very act of judging, they are supposed to be informed by their perceptions of what has come before. ${ }^{141}$ Thus, although the Civil War unquestionably remade the political and constitutional world, judges took comfort in antebellum precedents and proclaimed their dedication to orderly development of the law. They would make no radical exceptions. Admittedly, gang labor was generally eliminated and, at least for a time, many black women could choose not to work in the fields. But the postbellum status and working conditions of the black sharecropper or field hand often were no better, and sometimes were worse, than his place within the peculiar institution. ${ }^{142} \mathrm{He}$ was a free man contracting for his services, but only within a web of legal doctrines that forbade plantation owners to "entice" someone else's laborer, and criminal fraud statutes that promised prison and a chain gang, or the convict-lease system, if he tried to escape his contract. Moreover, the constant threat of extralegal enforcement assured that the former slave remained both on and in his place.

By 1883, the Supreme Court had determined in the Civil Rights Cases that:

When a man has emerged from slavery, and by the aid of beneficent legislation has shaken off the inseparable concomitants of that state, there must be some stage in the progress of his elevation when he takes the rank of a mere citizen, and ceases to be the special favorite of the laws ..... ${ }^{143}$

context of the case, see P. Daniel, The Shadow of Stavery: Peonage in the South, 1901-1969, at 3-18 (1972).

141. Justice AccusED, supra note 1, at 7 ("Judges, more than most men, are conscious of the baggage of the past.").

142. See P. Daniel, supta note 140 , at 1-42; D. Novak, The Wheel of Servitude: Black Forced LABOR AFTER SLAVERY (1978). Both books contain dramatic accounts of the exceptional judges who departed from the norm and condemned the peonage system. Apparently, there was a wave of such decisions just after the turn of the century. This phenomenon resists easy explanation. It may be directly connected to the political transformation of the South during that period, with Republican judges resisting Democratic Party domination. See J. Kousser, The ShaPING of SoutherN Politics: Suffrage Restriction and THE Establishment of THE ONe-Party South, $1880-1910$ (1974). Booker T. Washington's secret role in financing and plotting litigation strategy is described in P. DANIEL, supra note 140, at 65-81. In addition, the muckrakers and the Progressive movement provided some generalized impetus, despite discouragement from the Supreme Court. See Soifer, supra note 50, at 383, 397-98; see also United States v. Morris, 125 F. 122, 125 (D. Ark. 1903) ("Shall the Courts be less liberal in construing provisions in favor of freedom than those in favor of slavery?"); A. Bickel \& B. SCHMidT, THE Judiciary AND Responsible Government, 1910-1921, at 820-907 (1984); (vol. nine of Holmes Devise History of the Supreme Court of the United States). But see Kennedy, Race Relations Law and the Tradition of Celebration: The Case of Professor Schmidt, 86 Colum. L. REv. 1622 (1986) (critical view of celebratory tone of Bickel \& Schmidt).

143. 109 U.S. 3, 25 (1883). A disturbing echo of this argument by Justice Bradley occurred in Justice Powell's decisive opinion in Regents of the University of California v. Bakke, 438 U.S. 265, 295 (1978), where Powell asserted, "It is far too late to argue that the guarantee of equal protection to all persons permits the recognition of special wards entitled to a degree of protection greater than that accorded others." 
Following the conservative redemption of the South and accompanying the rise of virulent racism in the Jim Crow era, ${ }^{144}$ the Supreme Court retreated to a position of almost complete deference to whatever results politics or the market might yield.

Justice Holmes, for example, in one of his first majority opinions on the Supreme Court, concentrated on the enforcement problems if there were federal court review of disfranchisement claims. ${ }^{145}$ Because the blacks of Alabama alleged that "the great mass of the white population intends to keep the blacks from voting," Holmes wrote, the courts could provide no remedy unless they were "prepared to supervise the voting in that State by officers of the court."146 Therefore, the blacks were told that they should seek relief for "a great political wrong, if done," from the people of Alabama or from "the legislative and political department of the government of the United States."147

Two years after Holmes's opinion, and forty years after slavery's end, the Supreme Court determined in Hodges v. United States ${ }^{148}$ that "when the problem of the emancipated slaves was before the Nation," the nation "declined to constitute them wards of the Nation or leave them in a condition of alienage where they would be subject to the jurisdiction of Congress."140 Instead, as Justice Brewer explained for the majority, the emancipated slaves were given citizenship because the Nation "doubtless believ[ed] that thereby in the long run their best interests would be subserved, they taking their chances with other citizens in the States where they should make their homes."180

When courts impose sentences of death or imprisonment, they deal with pain and suffering. But they are also jurispathic, as Bob Cover emphasized, when they settle normative contests. ${ }^{151}$ And judges are hardly less jurispathic when they deny jurisdiction to just claims that demand to be heard. Forty years after slavery, instead of their promised land, blacks found themselves instructed to "tak[e] their chances" and thereby to hope for their best interests "in the long run." Judicial inaction, judicial failure to listen, also deals pain and death. Judges thereby commit themselves "to

144. J. Williamson, The Crucible of Race, supra note 93, at 109-223.

145. Giles v. Harris, 189 U.S. 475 (1903).

146. Id. at 488 .

147. Id.; see also Jones v. Montague, 194 U.S. 147 (1904) (suit filed by blacks disfranchised by 1901 Virginia constitution dismissed as moot since election for federal House of Representatives already held); Giles v. Teasley, 193 U.S. 146 (1904) (Court "not unmindful of gravity of charges against state," but since Supreme Court of Alabama held state law left qualifications for voter registration to board of registrars in judicial capacity, independent state law ground barred review by United States Supreme Court).

148. 203 U.S. 1 (1906).

149. Id. at 20; see supra note 140 (discussing Clyatt v. United States, 197 U.S. 207 (1905)).

150. 203 U.S. at 20.

151. Cover, Nomos and Narrative, supra note 3, at 53-60. 
survival of hierarchical authority first, and interpretive integrity or justice only secondarily."162 More gloomily still, the history I have related recalls Bob Cover's words: "History corrects for the scale of heroics that we would otherwise project upon the past."18s But Bob went on to suggest hope as well as painful remembrance: "Only myth tells us who we would become; only history can tell us how hard it will really be to become that."164 With new narratives, in other words, it might be possible to advance beyond the grand declarations of universal freedom that yielded only distant hope and bitter blues. We might do better than merely to reinstate competition of each against each and all against all according to the established rules of the game.

\section{Billy Budd: Matters 'Not So Susceptible of Proof'}

In Billy Budd, Herman Melville brilliantly dissects the pathology of judging; he also offers a strikingly apt, though at least double-edged, challenge to retrospective moral judgment. He succeeds in enticing his readers to identify directly with and yet to judge the characters in his story. After Captain Vere successfully bullies his drumhead court to convict Billy Budd and to order his execution, ${ }^{165}$ however, the narrator's flat voice returns, claiming not to render judgment but only to recall a similar event, the Somers mutiny incident in 1842. Melville's cousin presided over the court aboard the Somers and voted to convict and to execute a midshipman and two sailors in time of peace, not many days' sail from home-and we are told that even under those circumstances a naval court of inquiry on shore vindicated the decision to hang the alleged mutineers. ${ }^{158}$ The narrator then adds the sardonic and cryptic observation: "History, and here cited without comment."187

152. Id. at 58.

153. Cover, Folktales of Justice, supra note 3 , at $\mathbf{1 9 0}$.

154. Id.

155. After proclaiming that their loyalty is to the King, and not to Nature, by virtue of "these buttons that we wear," Vere tells the drumhead court:

But let not warm hearts betray heads that should be cool. Ashore in a criminal case, will an upright judge allow himself off the bench to be waylaid by some tender kinswoman of the accused seeking to touch him with her tearful plea? Well, the heart here, sometimes the feminine in man, is as that piteous woman, and hard though it be, she must here be ruled out.

Billy BuDd, supra note 39, at 362 . This dichotomous view of head and heart, male and female, is familiar in law, of course, and often used to explain the role of equity mitigating the masculine vigor of law. See, e.g., K. NEWMYER, supra note 40, at 291, quoting Story to exactly this effect. Vere advises the members of the court that their choice is binary: "We must do; and one of two things must we do, condemn or let go." BiLly Budd, supra note 39, at 363.

156. BILLY BuDd, supra note 39, at 365. For a provocative discussion of Melville and his family, and of the Somers incident (which gained considerable notoriety in part because one of those executed was the son of the Secretary of the Navy), see M. Rogin, Subversive Genealogy: The Politics and ART of Herman Melville (1983).

157. Billy BudD, supra note 39, at 365. 
Early in Billy Budd, however, Melville emphasizes how history sanitizes events. Throughout his work, Melville contrasts the "ragged edges" of "truth uncompromisingly told" with the misleading "symmetry of form" one finds in "fable" and "pure fiction."158 Thus, Melville's reliance on history "without comment" compounds the irony. Melville further emphasizes the ironic problem of retrospective judgment when the narrator next suggests a defense of Vere's verdict by proposing a formal principle, justified paradoxically by a fable. After Vere authorizes yet another "variance from usage"160 in his haste to have Billy Budd hanged, the narrator explains that this might be interpreted as evidence of the necessity for unusual action: "'With mankind,' [as Vere] would say, 'forms, measured forms, are everything; and this is the import couched in the story of Orpheus with his lyre spellbinding the wild denizens of the wood." "180 Though he underscores the difficulty of judging, Melville repeatedly compels the reader to make judgments and warns of the danger inherent in failure to judge.

Billy Budd rivets attention on a conflict: Captain Vere's obedience to formal rules and to his perceived duty contrasts sharply with the demands of actual justice. As Bob Cover wrote, Melville is "astonishingly successful in making his readers ask dreadful questions of Vere and his behavior."161 Bob forcefully extended this cross-examination to judges who opt for stability over the claims of natural rights. And, as Bob put it, "in portraying a man caught in the horrible conflict between duty and conscience, between role and morality, between nature and positive law," it would be

158. Billy Budd is "[a]n inside narrative" whose power derives from its being "spare, spectral, dualistic, historical fiction . . . [which] anticipates the Kafkaesque strand of literary modernism." $M$. RogIN, supra note 156, at 296. Melville's approach here is related, I think, to his repeated theme that history does not capture the bleakness of what actually occurred. For example, he wrote with irony of the Great Mutiny of 1797, which established the context for the removal of the Handsome Sailor from the Rights of Man to the Bellipotent: "Such events cannot be ignored, but there is a considerate way of historically treating them. If a well-constituted individual refrains from blazoning aught amiss or calamitous in his family, a nation in the like circumstance may without reproach be equally discreet." BILLy BudD, supra note 39, at 304.

159. BILLY BUDD, supra note 39, at 380 . The paradoxical relationship of "measured forms" and this "variance from usage" echoes a number of other references to "strict adherence to usage," id. at 369 , in contrast to departures from "usage" in Vere's rush to judgment. For a detailed argument that Melville sought to underscore the legal impropriety of Vere's actions, see R. WEISBERG, ThE FaILURE OF THE WORD 160-176 (1984).

160. Billy BuDD, supra note 39 , at 380 . The narrator has just said:

Says a writer whom few know, "forty years after a battle it is easy for a noncombatant to reason about how it ought to have been fought. It is another thing personally and under fire to have to direct the fighting while involved in the obscuring smoke of it. Much so with respect to other emergencies involving considerations both practical and moral, and when it is imperative promptly to act. . . . Little ween the snug card players in the cabin of the responsibilities of the sleepless man on the bridge."

161. Justice ACCUSED, supra note 1 , at 4. 
remarkable if Melville had been "untouched by the figure of his father-inlaw,"162 Lemuel Shaw, confronting actual slavery cases.

Inspired by what Bob Cover had to say about Shaw and other judges, I suggest that Herman Melville forces us to confront dreadful questions about our own detached obedience to law, our suppositions about individual autonomy, and ourselves. From this perspective, the minor character of the navy surgeon may be at the core of the story. Through the surgeon, Melville asks prescient questions, questions about cynicism and complacency in a world in which truth seems impossible to identify.

A century after Melville wrote Billy Budd, and forty years after the Holocaust, it is the surgeon who most powerfully poses the dreadful questions we face about insight, obedience, and complicity. ${ }^{183} \mathrm{In}$ all of us, though perhaps particularly in lawyers, there is some of Vere, some staunch unwillingness to deviate from settled forms. Yet we are probably more directly implicated in the innocent bystander, the Bellipotent's surgeon, than in Vere or Billy Budd. Few become captains or judges, but we all confront what the surgeon faced. Through him, we may recognize that truth is often elusive and that our unwillingness to fight for our best guesses about truth tends to produce anomie or, even worse, collaboration with evil.

The surgeon considers Vere's drumhead court at best "impolitic."164 He believes that in an extraordinary case such as that of Billy Budd, it certainly would accord with (and may even be dictated by) "usage" for Captain Vere to rejoin the squadron and refer the matter to the admiral. ${ }^{165}$ Not only is the surgeon "full of disquietude and misgiving," but he begins to think that Vere, the embodiment of authority on the ship, actually may be "unhinged."168 Unfortunately, the surgeon also knows that this suspicion is "not so susceptible of proof."167 Melville underscores the

\section{Id. at 5 .}

163. In the first piece he published in a law review as an Assistant Professor-Designate, Bob Cover used his rediscovery of R. Hildreth, Atrocious Judges: Lives OF Judges Infamous as TOOLS OF TYRANTS AND INSTRUMENTS OF OPPRESSION (1856) to comment on the Vietnam war and on the role of judges facing legal challenges "to the smooth functioning of the war machine." Cover, Book Review, 68 Colum. L. REv. 1003, 1006 (1968). He wrote with vigor and some harshness about the role of federal judges in the past, and he made explicit the connection between his intention to hold a mirror up to judges to show them that they are implicated in moral outrages perpetrated through legal process and his view that "the brutal lessons of Hitler and Stalin" ought to make judges "wary of making secular law ... the only standard for human conduct." Id. at 1005. Bob proclaimed: "With Nazi Germany fresh in our minds, with the screaming silence of the German people barely passed into history, the silence and, more, the cooperation of the federal bench demands comment." Id. at 1006. In a sense, my concern is on a less specific, perhaps more democratic level than Bob's repeated examination of the interrelationship of rules and rulers. I seek to ask Coveresque questions about all the rest of us.

164. Billy BuDd, supra note 39 , at 352 .

165. Id.

166. Id.

167. Id. This recalls the narrator's earlier discussion of an anonymous person called "an honest 
surgeon's dilemma about whether to act on his insight: "No more trying situation is conceivable," than that of a person who believes his commander is not entirely mad, "but yet not unaffected in his intelligence."168 Caught between choosing insolence or mutiny, the surgeon simply follows orders.

The next paragraph begins with a striking meditation on truth. Melville has the surgeon ponder: "Who in the rainbow can draw the line where the violet ends and the orange begins? Distinctly we see the difference of the colors, but where exactly does the one first blendingly enter into the other?"168 Here, indeterminancy is applied specifically to issues of sanity and insanity, but the narrator notes sardonically that " $[t]$ here is nothing nameable but that some men will, or undertake to, do it for pay."170 In the next paragraph, Melville tells his readers that "every one must determine for himself"171 whether Vere was the victim of any degree of aberration.

Melville's theme of the imperceptible degrees of truth, and the way in which professional training may blind even someone as perceptive as the surgeon, is presented more acutely near the end of Billy Budd. Chapter Twenty-six, a curious interruption of the flow of the story's denouement, describes an exchange between the surgeon and the purser concerning the motionlessness of Billy Budd's body at the moment he was hanged. The

scholar." Id. at 324. The scholar insists that he is an adherent of no organized religion and certainly not of any philosophical system, and he denigrates the use of "what is known as "knowledge of the world" " to "enter [someone's] labyrinth and get out again." Coke and Blackstone are even sillier examples of what may be taken to be knowledge, the scholar adds, since they "hardly shed so much light as the Hebrew prophets." And he points out that the prophets were "[m]ostly recluses." Id. at 325.

168. Id. at 353. Here Melville may have been intentionally providing a variation on a theme from R. Dana, Two Years Before the Mast: A Personal. Narrative of the Sea (1840) Richard Henry Dana, Jr. expresses revulsion about a shipboard flogging, yet notes "If a sailor resist his commander, he resists the law, and piracy or submission are his only alternatives." Id. at 95-96. For a fine comparative treatment of Dana and Melville, see R. Ferguson, supra note 13, at 263-72. Ferguson argues that the movement of nineteenth-century American literature generally was "toward an increasingly personal stance and away from social affirmations, toward what Herman Melville would call the capacity to say 'NO! in thunder.' "Id. at 58 (quoting letter from H. Melville to N. Hawthorne (Apr. 16, 1851) in The Portable Melville 423 (J. Leyda ed. 1952)).

169. Id. The error in the ordering of the colors in the spectrum may make a further point about what we see and what we know. In another famous passage, Melville says: "In this world of lies, truth is forced to fly like a scared white doe in the woodlands; and only by glimpses will she reveal herself, as in Shakespeare and other masters of the great Art of telling the truth even though it be covertly and by snatches." H. Melville, Hawthome and His Mosses, in The Portable Melville 400, 408 (J. Leyda ed. 1952).

170. Billy BudD, supra note 39, at 353. Elsewhere, Melville compares Claggart's approach to Billy Budd to "the measured step and calm collected air of an asylum physician." Id. at 349. Melville may have been particularly attuned to the difficulties of distinguishing sanity and insanity in a detached way because his own family had worried about his sanity in the early 1850's and even arranged for a consultation, apparently with Dr. Oliver Wendell Holmes. See H. Melville: SELECTEd Tales ANd Poems at vii (R. Chase ed. 1950); M. Rogin, supra note 156, at 186.

171. Billy Budd, supra note 39, at 353. Thus, Melville emphasizes the difficulty of judging yet tells us that we must be active readers. 
purser, "more accurate as an accountant than profound as a philosopher," believes this "singularity" a remarkable testament to will power. ${ }^{172}$ But the surgeon, described here as "one in whom a discreet causticity went along with a manner less genial than polite," explains that the normal movement at a death by hanging results merely from a mechanical spasm, and is "no more attributable to will power . . . than to horsepower." The surgeon ultimately must concede that the absence of spasmodic movement was "phenomenal," but he takes this to mean only that "it was an appearance the cause of which is not immediately to be assigned."174 Once the surgeon categorizes a problem as "imaginative and metaphysical-in short, Greek," 175 he assumes that his ability to pigeonhole has achieved the proper limit for his engagement. The surgeon abruptly changes tone, we are told, using the ironic excuse that he has a case in sick bay "that I do not care to leave to my assistants." ${ }^{\text {"176 }}$ Melville concludes the digression in this chapter with what seems, at a minimum, a significant double pun concerning the surgeon: "And rising from the mess he formally withdrew."177

We know the surgeon is aware of indeterminacy. This makes his formal withdrawal from "the mess" and from personal judgment, excused with a claim of professional commitment, even more apt and more problematic for us than Vere's decision to resolve the "jugglery of circumstances" according to his "vows of allegiance to martial duty," rather than on "a primitive basis."178 Similarly, the challenge in Betty's Case, as in the moral-formal dilemmas that Bob Cover considered throughout his work, is to decide when to confront rules and when to accept them, when to leave people alone and when to intervene. It is not only captains and judges who must decide when to challenge the ordinary rules of orderly conduct. Bob Cover and Herman Melville powerfully delineate the jurisdictional lines that may sometimes contain force, but that also tend to confine justice. The surgeon, like us, knows that much is unknowable and more is "not so susceptible of proof." His plight and his retreat into formalism and duty speak to us, and to our possibilities and limitations in thinking with skeptical realism about law.

172. Id. at 376 .

173. Id.

174. Id. at 377.

175. Id.

176. Id.

177. Id.

178. Id. at 354. Robert Ferguson argues that Melville borrowed heavily from the professional orthodoxy popularized by Langdell, Holmes, and others in the second half of the nineteenth century in presenting Vere's opinions. Ferguson states: "Unmistakably, it is precision of language, and excluding logic, insistence upon context, and an overruling distrust of moral philosophy-traits of the modern professional-that kill Billy Budd." R. Ferguson, supra note 13 , at 289. 


\section{Conclusion}

I have told a bleak story, one that highlights the irony and the danger of leaving tough issues of paternalism and autonomy to captains and judges. I have no panacea, no grand normative premise to help them or us sort out the conundrum.

Yet it is worth remembering that Bob Cover never lost hope, not even for law. He never stopped believing that "legal meaning is a challenging enrichment of social life, a potential restraint on arbitrary power and violence."179 I think that the Second Reconstruction after a century of tragic delay, and Bob's own involvement in it, ${ }^{180}$ helps explain his optimism in the face of the sobering complexity he helped us see in legal history. He urged that we keep on telling and creating heroic tales-what Bob celebrated as sacred narratives of jurisdiction and as myths of constitutional constraint and entitlement. I think that Bob saw constitutionalism as mythic and, therefore, as incredibly worthwhile. Bob was iconoclastic, not nihilistic. He emphasized that law matters in specific decisions. ${ }^{181} \mathrm{He}$ also passionately sought to rethink and to use law "to invite new worlds."182

I do not know if Bob remembered how Carl Becker once described historians. I always meant to give these words to Bob, but I assumed that there would be time enough, even for someone of my absent-minded, procrastinating ways. Becker's words fit Bob Cover and would have amused him. Becker said historians are part of "that ancient and honorable company of wise-men of the tribe, of bards and story-tellers and minstrels, of soothsayers and priests, to whom in successive ages has been entrusted the keeping of useful myths."'183

Biblical narratives provide the paradigm for narratives that bind and educate. It is surely no coincidence that Bob knew and continued to study Bible and Talmud. He delighted in discovering rebellious elders, second sons who inherited despite the clear rules that provided only for the eldest, rabbis in Safed who argued with Jerusalem about reinstating the rabbinic

179. Cover, Nomos and Narrative, supra note 3, at 68.

180. Bob often referred to law as a bridge, perhaps the only bridge from the limitations we learn from the past and the promising possibilities we can pursue for the future. Cover, Folktales of Justice, supra note 3, at 181; Cover, Nomos and Narrative, supra note 3, at 9. This hope may help explain his decision as an undergraduate to give up a fellowship to study Chinese in order to work in the civil rights movement in Georgia, where he spent several weeks in jail for acting on his beliefs. It is also probably related to the unusual decision by a great abstract thinker, as Bob unquestionably was, to relocate his office to the chaotic and nitty-gritty world of the Yale Legal Services Organization. Bob wanted to be in the middle of the tumult there, to be available to help with the minutiae of civil procedure, for example, because he believed deeply that lawyering for the right causes is not just admirable, it is vitally important to seeking justice.

181. See, e.g., JUSTICE ACCUSED, supra note 1, at 81-82.

182. Cover, Nomos and Narrative, supra note 3 , at 68 .

183. See G. Becker, Every Man His Own Historian: Essays on History and Politics 231 (1935). 
line, and other examples of people who knew when to make exceptions to rules, without losing sight of the importance of rules themselves.

The Bible tells us that it took the Israelites forty years to reach the promised land. They were not the same people who escaped from Egypt, and the promised land proved to be anything but Eden. There are many interpretations of the Exodus and of the repeated murmurings of the people in the desert. I prefer an interpretation of the forty years of wandering that urges us to strive for freedorn in a better world, despite the repeated setbacks our own limitations as well as arbitrary powers may impose. Maimonides explained that the Lord "used a gracious ruse in causing [the people] to wander perplexedly in the desert until their souls became courageous . . . and until, moreover, people were born who were not accustomed to humiliation and servitude."184 Viewing the years of wandering in the wilderness as a "new school for the soul"185 underscores the importance of knowing, and transcending, the past.

Bob Cover taught and demonstrated that "A great speaker or writer of the language ordinarily acts according to the rules but knows when and how to ignore them as well." ${ }^{186} \mathrm{He}$ celebrated prophets more than priests. Bob gave us hope for legal progress and help in recognizing the narrative claims of those squeezed into near silence by our ambivalence about the contest between legal rights and legal power.

Bob Cover's example inspires us to keep marching through the wilderness. And we all must decide which narratives from the past to condemn and which to honor. Ancient tales will accompany our march, and so will the rhythms and new stories of different drummers.

184. M. Waizer, supra note 48, at 54 (quoting M. Maimonides, The Guide for the PerPLEXED 1:526-28 (3.32.70a and b).

185. Id. at 43 (elaborating upon Anthony Hecht's poem Exile).

186. Justice ACCUSED, supra note 1, at 127. 